\title{
FOTOGRAMETRIA, POLITYKA I PRZEDSIĘBIORCZOŚĆ A INWENTARYZACJA ZABYTKÓW. ALBRECHT MEYDENBAUER W POZNAŃSKIEM W ROKU 1885 I 1887
}

Fotogrametria, czyli technika fotograficzna pozwalająca na podstawie zdjęć odtworzyć odległości w terenie lub wymiary budowli, w zamyśle jej wynalazców miała służyć jako środek wykonywania pomiarów na potrzeby sporządzania map czy obliczania np. dystansu od stanowiska dział do murów obleganego miasta. Określanie wymiarów budowli nie było wymieniane jako cel nowej techniki - zarówno Aimé Laussedat we Francji, jak i Albrecht Meydenbauer w Prusach dążyli do zainteresowania swym wynalazkiem przede wszystkim dowódców wojskowych. Laussedatowi udało się zarówno zdobyć, jak i utrzymać uwagę armii, natomiast Meydenbauer, po porażce pomiarów wykonywanych podczas oblężenia Strasburga w roku 1870, musiał zmienić kierunek swych wysiłków. Za cel obrał włączenie techniki fotogrametrycznej do inwentaryzacji zabytków. Chciałabym przedstawić działania podjęte przez niego w tym celu jako szeroko zakrojoną mobilizację zasobów - sojuszników, funduszy i odbiorców, rozwijaną w relacjach między konkretnymi aktorami społecznymi, nie zaś jako bezproblemowe wdrożenie w wyniku odpersonalizowanego, „powszechnego" zainteresowania zabytkami w XIX wieku.

W ramach tych sieci kontaktów zdarzenia były generowane, czyli konstytuowane stopniowo na drodze prób i błędów, w odniesieniu do napotykanych ograniczeń i pojawiających się możliwości - nowych koneksji, źródeł finansowania czy ulepszonych materiałów fotograficznych ${ }^{1}$. Meyden-

${ }^{1} \mathrm{O}$ modelu generatywnym kultury oraz zastosowaniu pojęcia transakcji w naukach społecznych zob. F. Barth, W strone pełniejszego opisu i głębszej analizy zjawisk kulturowych, w: Badanie kultury. Kontynuacje, red. M. Kempny, E. Nowicka, Warszawa 2004, s. 180-192; F. Barth, A Personal View of Present Tasks and Priorities in Cultural and Social Anthropology, w: Assesing Cultural Anthropology, red. R. Borowsky, New York 1994, s. $349-361$. 
bauer musiał szukać sposobów, za pomocą których wykreowałby zbieżność fotogrametrii $z$ interesami osób, które mogły ją finansowo wesprzeć lub takie wsparcie pozyskać. Chcę szczegółowo przeanalizować, jakimi możliwościami dysponował, jak próbował je wykorzystać i czy udało mu się stworzyć nowe. Odwołam się przy tym do badań Bruno Latoura nad procesami powstawania, introdukcji i popularyzacji wynalazków naukowych i technicznych ${ }^{2}$.

Meydenbauer dwukrotnie przebywał w Prowincji Poznańskiej, jednak nie interesował się tamtejszymi obiektami ani „kwestią polską". To minister wyznań Gustav von Gossler zlecił Meydenbauerowi wykonanie zdjęć rotundy pw. św. Prokopa w Strzelnie, najpierw w roku $1885^{3}$, a następnie dwa lata później. Przy okazji tego drugiego pobytu w Poznańskiem Meydenbauer uwiecznił też ruiny romańskiego kościoła w Inowrocławiu oraz ratusz w Poznaniu i tamtejszy kościół Dominikanek ${ }^{4}$. Nie były to rutynowe przedsięwzięcia,

2 Zob. B. Latour, Krwiobieg nauki. Przykład naukowej inteligencji Joliota, w: idem, Nadzieja Pandory, tłum. K. Abriszewski, A. Derra, M. Smoczyński, M. Wróblewski, M. Zuber, Torun 2013, s. 113-148.

${ }^{3}$ R. Meyer, Albrecht Meydenbauer. Baukunst in historischen Fotografien, Leipzig 1985, s. 38.

${ }^{4}$ W Poznaniu znajdują się dwa zbiory tych zdjęć: album przechowywany w Muzeum Historii Miasta Poznania oraz odbitki (bez fotografii zabytków poznańskich) w Pracowni Zbiorów Ikonograficznych Biblioteki Uniwersyteckiej. Ich badaniem zajmowali się M. Mrugalska-Banaszak i M. Danielewski, jednak ich publikacje zawierają nieścisłości, przekładające się na błędne wnioski, np. nazwisko fotografa odczytano jako "Meydenlender”, mimo iż w „Kurierze Poznańskim” zapisano je jako „Meydenlauer”, popełniając jedną literówkę przy przepisywaniu z „Posener Zeitung”; gazeta niemiecka podała, że w Hôtel de Dresde 13 sierpnia zameldował się „Reg.- und Baurath Dr. Meydenbauer aus Berlin”, zdjęcia wykonał zaś dnia następnego, jednak badacze za „Kurierem Poznańskim” określili daty pobytu fotografa w mieście na 12 i 13 sierpnia (piątek i sobotę); M. Mrugalska-Banaszak tłumaczyła widoczne na zdjęciach zamknięte sklepy przerwą obiadową, tymczasem był to dzień wolny od pracy - niedziela; nie sprawdzono też kolejnych numerów „Posener Zeitung”, natomiast w jednym z nich pojawiła się informacja o kolejności pobytów Meydenbauera w Inowrocławiu i Strzelnie; nie zapoznano się też ze szczegółami technicznymi rozwoju fotogrametrii, przez co M. Danielewski stawiał błędne hipotezy nt. podróży fotografa, zakładając, że odbywał ją zwykłymi drogami, tymczasem podatność sprzętu na uszkodzenia i rozregulowanie pod wpływem wstrząsów wymagała transportu koleją; nieznajomość zmian w konstrukcji aparatu przekładających się na wygląd negatywów uniemożliwiła też M. Danielewskiemu rozstrzygnięcie kolejności powstawania zdjęć ze Strzelna; nie zapoznano się też z realiami funkcjonowania kierowanego przez Meydenbauera Instytutu Fotogrametrii i przyjęto za pewnik, że misja fotografa ograniczała się do Poznania, Inowrocławia i Strzelna, co byłoby nieopłacalne; pomyłka w odczytaniu nazwiska sprawiła też, że badacze nie próbowali poznać tychże realiów, sądzili bowiem, iż szukają informacji na temat innego człowieka; zob. M. Mrugalska-Banaszak, 
gdyż dokumentacja fotogrametryczna miała być zarezerwowana dla „ważniejszych budowli, które z punktu widzenia historii sztuki odznaczają się wysoką rangą, a zarazem muszą zostać poddane gruntownej naprawie w krótkim czasie" $^{\prime 5}$. Moim kolejnym celem jest zatem weryfikacja, co w oczach ministra Gosslera decydowało o „ważności” akurat tych obiektów wielkopolskich oraz jak doszło do tego, że w ogóle zwrócił na nie uwagę.

\section{PODSTAWY ANALIZY}

Oczywiście łatwo byłoby wyjaśnić tę sytuację, przyjmując założenie, że misja Meydenbauera wpisywała się w zaplanowane działania władz, dążących do politycznego zawłaszczenia wielkopolskiego dziedzictwa oraz wzmacniania niemieckiej tożsamości narodowej. W konsekwencji jednak przenieślibyśmy współczesny język i współczesne rozumienie na warunki dziewiętnastowieczne. Kategoria „dziedzictwa” (Kulturerbe) została bowiem spopularyzowana dopiero w XX wieku ${ }^{6}$ - jeśli używa się jej w odniesieniu do wcześniejszego stulecia, to wówczas ulegają spłaszczeniu skomplikowane operacje, które doprowadziły do obecnego sposobu jej rozumienia. „Dziedzictwo" funkcjonuje dziś jako „czarna skrzynka”, czyli - zgodnie z ujęciem Bruno Latoura - fakt uważany za oczywisty ${ }^{7}$. Niemal nikogo nie interesuje, jaka różnorodność elementów się na niego złożyła - liczy się tylko „to, co na wejściu” i „to, co na wyjściu”.

Jeden dzień z ratuszem w tle. Poznań 13 sierpnia 1887, Poznań 2004; M. Danielewski, Romańskie zabytki architektury sakralnej Inowrocławia i Strzelna w świetle fotografii Meydenlendera z 1887 roku, „Archiwa Biblioteki i Muzea Kościelne” 2012, 98, s. 27-50; idem, Reliefy z murów kościoła Panny Marii w Inowrocławiu, „Roczniki Historyczne” 2011, 76, s. 7-34; idem, Fotografie z 1887 roku jako źródło ikonograficzne badań nad romańskq architekturq sakralnq Strzelna, w: Z dziejów pogranicza kujawsko-wielkopolskiego, t. 3, red. D. Karczewski, M. Wilczek-Karczewska, Strzelno-Kruszwica 2015, s. 105-120; „Kurier Poznański” 17 sierpnia 1887, s. [4]; „Posener Zeitung” 13 sierpnia 1887 , s. 3; „Posener Zeitung” 16 sierpnia 1887, s. 6.

${ }^{5}$ Raport Gosslera do cesarza, za: Meyer, Albrecht Meydenbauer..., s. 38.

${ }^{6} \mathrm{~W}$ języku niemieckim określano zabytek mianem „pomnika” (Denkmal), stąd też pojęcie ochrony zabytków jako „opieki nad pomnikami” (Denkmalpflege), popularne zwłaszcza od lat 80. XIX w., zob. A. Swenson, „Heritage”, „Patrimoine” und „Kulturerbe”: Eine vergleichende historische Semantik, w: Prädikat „Heritage”. Wertschöpfungen aus kulturellen Ressourcen, red. R. Bendix, D. Hemme, M. Tauschek, Münster 2007, s. 53-74.

7 Ł. Afeltowicz, Laboratoria $w$ działaniu. Innowacja technologiczna $w$ świetle antropologii nauki, Warszawa 2011, s. 69. 
Uproszczeniem byłaby też interpretacja państwowych działań konserwatorskich jako podejmowanych wyłącznie $\mathrm{w}$ interesie narodowym i przeciw Polakom. Publiczne wypowiedzi, w których autor próbował wciągnąć dany zabytek w dyskurs rywalizacji niemiecko-polskiej, trzeba analizować pod kątem ich realnej sprawczości - cóż bowiem z tego, że dany poseł wyliczałby w Landtagu budowle, które jego zdaniem symbolizowały wyższość niemieckiej kultury nad polską, gdyby reszta posłów nie zwróciła na niego uwagi lub wręcz ukróciła jego zapędy? To, że dany poseł starał się o zideologizowanie przedsięwzięcia, nie znaczyło przecież, że wszyscy niemieccy deputowani poddali się jego sugestiom.

Chcę przyjrzeć się formacji państwowego aparatu ochrony zabytków oraz włączonej w niego fotogrametrii jako stopniowo wprowadzanym projektom, które porównałabym do eksperymentowania. Powoływanie określonych instytucji, organizacja kształcenia odpowiednich kadr, szukanie technik i metod usprawniających prowadzenie dokumentacji odbywało się na drodze wdrażania jednych czynników i marginalizacji innych. Z początkowej skomplikowanej sytuacji próbowano wyodrębnić rozwiązania poddające się manipulacji, przewidywalne, ekonomiczne, a zatem możliwe do standaryzacji i wdrożenia ${ }^{8}$.

Realne warunki były jednak dalekie od środowiska i procedur laboratoryjnych - zmienne nie były wyizolowane, wchodziły ze sobą w różne związki o różnych konfiguracjach, nie były też systematycznie obserwowane, dlatego trudno było ocenić, co i dlaczego działało zgodnie z oczekiwaniami. Nie mamy tu do czynienia z precyzyjną taktyką i jej implementacją - przebieg działań był często chaotyczny, „zygzakowaty”, a nie liniowy, jak mogłoby się wydawać, gdybyśmy rozpatrywali tylko udane przedsięwzięcia. Podejmowane próby często bazowały na przejmowaniu rozwiązań, które sprawdziły się $\mathrm{w}$ wykonaniu innych i w innych okolicznościach, zgodnie $\mathrm{z}$ potocznym przekonaniem, że jeśli coś udało się gdzie indziej, to będzie efektywne także u nas ${ }^{9}$. To w tym kontekście chciałabym przeanalizować zarówno dobór środków w propagowaniu fotogrametrii, jak i stopniowy wzrost popularności dyskursu narodowego w wypowiedziach dotyczących zabytków - nie tylko w pismach wojujących literatów, historyków czy filozofów, ale też w debatach polityków.

${ }^{8}$ O procedurach eksperymentowania zob. ibidem, s. 18-23; W. Sady, Spór o racjonalność naukowa. Od Poincarégo do Laudana, Torun 2013, s. 225-227.

9 F. Barth, "Models" reconsidered, w: idem, Process and form in social life. Selected essays of Fredrik Barth, t. 1, London 1981, s. 100. 


\section{MOBILIZACJA ŚWIATA - POCZĄTKI FOTOGRAMETRII W PRUSACH}

Pierwsze próby fotogrametryczne przeprowadzane przez Meydenbauera możemy określić jako eksperymenty techniczne par excellence. Interesuje mnie nie tyle proces projektowania i konstrukcji urządzenia, ile raczej sposób, w jaki końcowy produkt musiał zostać introdukowany „na rynku”. Ustalone praktyki towarzyszące takiemu wprowadzeniu miały moc potwierdzenia wiarygodności tego, co oferowała fotogrametria, dlatego kolejne kroki Meydenbauera, a potem jego sojuszników, mogą być zrozumiane tylko w odniesieniu do tych praktyk.

W każdym opracowaniu dotyczącym wynalazku Meydenbauera „punktem zero" jest rok 1858, w którym Meydenbauer jako młody student architektury omal nie spadł z wieżyczki katedry w Wetzlarze, której pomiarów dokonywał, i które to zdarzenie sprawiło, że zaczął się zastanawiać nad bezpieczniejszymi metodami ustalania wymiarów budowli ${ }^{10}$. Szczegółowy opis wypadku, przypominający odtwarzanie zdarzenia w zwolnionym tempie, pojawił się w spisywanych od roku 1914 wspomnieniach ${ }^{11}$ - narracja przywodzi na myśl kreację legendarnych początków metody jako genialnego olśnienia („Eureka!”). Nacisk, który Meydenbauer kładł na umocowanie źródeł pomysłu w latach 50., czyni prawdopodobnym, że przez opowieść wetzlarską Meydenbauer podkreślał swą niezależność od innych ówczesnych eksperymentów z fotografią metryczną - także od prac Aimégo Laussedata. Jak jednak sugerował w roku 1948 Louis Ragey, o rozwiązaniach Francuza Meydenbauer mógł się dowiedzieć $z$ artykułu na ich temat, opublikowanego w Prusach w roku $1865^{12}$.

Faktycznie dopiero w roku 1865 Meydenbauer wykonał pierwsze rysunki na podstawie zwykłych fotografii, twierdził jednak, że opracował je po konsultacjach ze swoim dawnym kolegą ze studiów w berlińskim Instytucie Przemysłowym, Heinrichem Hermannem Voglem, kierującym utworzonym

${ }^{10}$ Meyer, Albrecht Meydenbauer..., s. 15-16; J. Albertz, Albrecht Meydenbauer - Pioneer of photogrammetric documentation of the cultural heritage, w: Surveying and Documentation of Historic Buildings, Monuments, Sites: Traditional and Modern Methods. Proceedings of the XVIII International Symposium of CIPA 2001, Potsdam (Germany), September 18-21, 2001, red. J. Albertz, ICOMOS, UNESCO, ISPRS, Berlin 2002, s. 19.

11 Zaczął je spisywać dopiero od roku 1914, zob. A. Grimm, A. Meydenbauer, 120 Jahre Photogrammetrie in Deutschland. Tagebuch von Albrecht Meydenbauer, dem Nestor des Messbild-Verfahrens, veröffentlicht aus Anlass des Jubiläums 1858/1978, red. A. Grimm, Oldenbourg 1978, s. 5.

12 L. Ragey, The Work of Laussedat and Education in Photogrammetry at the National School of Arts and Crafts, Paris, „Photogrammetric Engineering” 1952, 1(18), s. 23. 
w tymże Instytucie laboratorium fotochemicznym ${ }^{13}$. Vogel jako organizator pierwszej Międzynarodowej Wystawy Fotografii w Berlinie umożliwił Meydenbauerowi zaprezentowanie na niej jego prac, jednak nie wzbudziły one większego zainteresowania. Fotografia, zaliczana do dziedziny chemii, wraz $z$ innymi naukami stosowanymi cieszyła się o wiele niższym poważaniem niż nauki uniwersyteckie ${ }^{14}$. Berlińskie uczelnie techniczne - Akademia Budowlana (Bauakademie), kształcąca przyszłych urzędników służby państwowej, oraz Instytut Przemysłowy (Gewerbeinstitut), w którym szkolono zaplecze kadrowe prywatnego przemysłu, nie miały statusu szkół wyższych ${ }^{15}$. Jako szkoły zawodowe teoretycznie służyły wyłącznie nauczaniu, nie zaś działalności badawczej. Skuteczny i systematyczny rozwój wynalazków fotograficznych byłby możliwy, gdyby uległo poprawie ogólne podejście do nauk stosowanych. Część posłów pruskich dostrzegała wprawdzie, że w Berlinie za mało promuje się nauki ścisłe, i od roku 1861 wysuwała pomysły na utworzenie politechniki przez połączenie Bauakademie i Gewerbeinstitut, jednak te inicjatywy długo nie mogły doczekać się realizacji ${ }^{16}$.

Głównym problemem były kwestie finansowania, dlatego pierwszą ${ }^{17}$ pruską politechnikę udało się powołać nie w Berlinie, a w Akwizgranie ${ }^{18}$, gdyż fundusze zapewniło tamtejsze Stowarzyszenie na rzecz Promocji Zatrudnienia (Aachener Verein zur Beforderung der Arbeitsamkeit). Rząd długo nie był zbyt zainteresowany dalszym rozwojem szkoły - podobnie jak w przypadku drugiej politechniki na terenie państwa, czyli uczelni w Hanowerze. Kwestią przyszłości było przekonanie, że szkolnictwo techniczne i prywatny przemysł

${ }^{13}$ R. Sachsse, Vogel, Hermann Wilhelm (1834-1898). German inventor, photographer, w: Encyclopedia of nineteenth-century photography, red. J. Hannavy, New York 2008, s. 1456.

${ }_{14}$ Das Preußische Kultusministerium als Staatsbehörde und gesellschaftliche Agentur (1817-1934), t. 1.1: Die Behörde und ihr höheres Personal. Darstellung, red. W. Neugebauer, Berlin 2009, s. 41.

15 W. König, Technical education and industrial performance in Germany. A triumph of heterogeneity, w: Education, Technology and Industrial Performance in Europe, 1850 1939, red. R. Fox, A. Guagnini, Cambridge 1993, s. 68.

16 R. Rürup, Die Technische Universität Berlin 1879-1979. Grundzüge und Probleme ihrer Geschichte, w: Wissenschaft und Gesellschaft. Beiträge zur Geschichte der Technische Universität Berlin 1879-1979, red. R. Rürup, Berlin1979, s. 10.

${ }_{17}$ Wcześniej utworzono politechnikę w Hanowerze, jednak nie powstała ona z inicjatywy pruskiej, lecz tylko znalazła się w granicach Prus po aneksji Hanoweru w roku 1866, zob. König, Technical education..., s. 69.

${ }_{18}$ W. Treue, Wirtschafts- und Technikgeschichte Preussens, Berlin-New York 1984, s. 570. 
przysłużą się ogólnemu rozwojowi techniki, na którym skorzysta też gospodarka państwowa.

Przedstawiciele nauk stosowanych, w tym eksperymentatorzy w zakresie technik fotograficznych, musieli dopiero budować swoją pozycję. Gdyby Meydenbauer próbował przebić się jako wynalazca w dziedzinie fotografii, zapewne jeszcze długo starałby się o zyskanie uwagi osób, których jego metoda mogła zainteresować. Miał jednak możliwość propagowania swego wynalazku jako przedstawiciel o wiele bardziej prestiżowego zawodu - jako architekt. Tylko przez część okresu studiów Meydenbauer uczył się bowiem w Instytucie Przemysłowym - ostatecznie ukończył Akademię Budowlaną, a po zdaniu egzaminów państwowych uzyskał uprawnienia do pracy w służbie publicznej. Meydenbauer mógł zatem zostać członkiem Stowarzyszenia Architektów Berlińskich, do którego wstąpił na początku kwietnia 1866 roku - w efekcie jeszcze przed końcem miesiąca zaczął popularyzować swoje prace, wygłaszając wykład o możliwościach zastosowania „obrazów pomiarowych” w badaniach budynków i terenu ${ }^{19}$. Przede wszystkim zaś zyskał dostęp do coraz bardziej liczącego się medium, czyli ogólnokrajowej prasy fachowej - jego wykład został opublikowany na początku roku 1867 w piśmie „Zeitschrift für Bauwesen”20. Jeszcze przed wybuchem wojny prusko-austriackiej w roku 1866 udało mu się przyciągnąć uwagę generała Ludwiga von Wasserschlebena, generalnego inspektora Korpusu Inżynierów. Generał zapewnił Meydenbauerowi wsparcie Ministerstwa Wojny - na jego koszt miały zostać wykonane próbne zdjęcia fotogrametryczne ${ }^{21}$. Proponuję przyjrzeć się przebiegowi tego przedsięwzięcia oraz jego opisowi jako specjalnie przygotowanej introdukcji naukowego wynalazku, określanej przez Bruno Latoura mianem inscenizacji ${ }^{22}$.

\section{INSCENIZACJA, CZYLI O METODZIE MOBILIZACJI SOJUSZNIKÓW}

Odwołując się do koncepcji Latoura, chcę podkreślić, że nawet w przypadkach, gdy wynalazki powstawały w odpowiedzi na konkretne potrzeby, ich funkcjonowanie jako spełnienie tych potrzeb musiało zostać dopiero ustanowione. Gdy np. Ludwik Pasteur podczas epidemii dziesiątkującej stada bydła we Francji wyselekcjonował bakterię wąglika, powodującą tę epidemię, oraz na drodze eksperymentów wytworzył szczepionkę, musiał przekonać hodowców,

19 Meyer, Albrecht Meydenbauer..., s. 55.

${ }^{20}$ Ibidem.

${ }^{21}$ [A. Meydenbauer], Die Photogrammetrie, „Wochenblatt Architekten-Vereins zu Berlin" 1867, 1(49), s. 471.

22 Afeltowicz, Laboratoria w działaniu..., s. 22. 
że to jest właśnie rozwiązanie ich problemów ${ }^{23}$. Co więcej, musiał mieć na tyle silne argumenty, by skłonić rolników nie tylko do stosowania szczepionki, ale przede wszystkim - do podjęcia odpowiednich działań prewencyjnych, obejmujących głównie ścisłe przestrzeganie zasad higieny w gospodarstwach. Szczepionka sama w sobie była bowiem zbyt słaba, by zadziałać w „standardowych" warunkach. Latour tym samym wskazywał, że aby wynalazek poprawnie funkcjonował, potrzebne jest zbudowanie dla niego „infrastruktury” - sama lokomotywa nie pojedzie bez torów. Inwestycja w „infrastrukturę" zazwyczaj wiąże się z dużymi wydatkami, dlatego Pasteur zainscenizował pokaz dla prominentów, w tym polityków, w którym zademonstrował działanie swej szczepionki. Pokaz odbył się w specjalnie przygotowanym, laboratoryjnie czystym gospodarstwie, po licznych próbach, po których Pasteur wiedział na pewno, że zaszczepiony przez niego okaz nie zachoruje. W ten sposób chciał utwierdzić odbiorców w słuszności ich decyzji o finansowaniu jego badań, a także przekonać ich do podjęcia dalszych, o wiele kosztowniejszych kroków.

Meydenbauer znajdował się w trudniejszej sytuacji, gdyż nie był, jak Pasteur, już uznanym badaczem ani też jego wynalazek nie odpowiadał na problemy wymagające pilnego rozwiązania. Meydenbauer musiał nie tylko poinformować szerokie kręgi polityków i architektów o istnieniu swej metody, ale też przekonać ich, że będzie użyteczna dla ich domniemanych celów. Publiczny pokaz możliwości fotogrametrii dałby naoczny dowód jej skuteczności. Oczywiście taki sposób „wprowadzenia w świat” nie został wymyślony ani przez Pasteura, ani przez Meydenbauera. Prezentację eksperymentów naukowych na oczach świadków praktykowali angielscy empiryści w XVII wieku, przeciwstawiając się dotychczasowemu wizerunkowi odizolowanego od świata filozofa lub alchemika ${ }^{24}$. Nowa nauka miała udowadniać na oczach wszystkich, że jej twierdzenia mają oparcie w rzeczywistych zjawiskach i stanowią odzwierciedlenie praw naturalnych.

W połowie XIX wieku o skuteczności wynalazków decydowały komisje złożone ze specjalistów w danej dziedzinie. Aimeé Laussedat, oficer Korpusu Inżynieryjnego, od roku 1849 eksperymentujący z wykorzystaniem obrazów w pomiarach terenu, również został poproszony o przeprowadzenie „pokazu” dla tego typu komisji. Zanim jednak do tego doszło, latami wypróbowywał różne rozwiązania, by w końcu opracować projekt fototeodolitu, będącego połączeniem instrumentu geodezyjnego $z$ aparatem fotograficznym. To z jego pomocą w roku 1861 Laussedat przeprowadził pokazowe pomiary w wiosce

${ }^{23}$ Ibidem, s. 67.

${ }^{24}$ S. Shapin, The house of experiment in seventeenth-century England, "Isis" 1987, $3(79)$, s. 374 . 
Buc pod Paryżem, w obecności komisji złożonej z oficerów Korpusu Inżynierów Gwardii Imperialnej ${ }^{25}$. Laussedat przez trzy godziny wykonał osiem zdjęć, na podstawie których w ciągu czterech dni wyrysował mapę obszaru obejmującego ok. 200 hektarów. Uzyskany stopień dokładności sprawił, że metoda Laussedata została uznana za użyteczną dla wojska, zwłaszcza jako pomoc w rozpoznaniu terenu w trakcie działań wojennych. Była to przepustka gwarantująca fundusze na dalsze prace i rozwój kariery - nie tylko wojskowej, ale i naukowej.

\section{„NAOCZNOŚĆ” NIE WYSTARCZY}

Procedura demonstracji poprawności działania wynalazku była podobna u Meydenbauera. Pomiary przeprowadzono w okolicy miasteczka Fryburg nad rzeką Unstrut, obejmując nimi obszar ok. 199 hektarów ${ }^{26}$, czyli teren niemal o tej samej powierzchni jak okolice Buc. Przygotowania trwały dwa dni, a wykonywanie 21 zdjęć drugie tyle. Jednak sam pokaz nie był równie efektywny co w przypadku Laussedata, gdyż zasadnicza część realizacji zadania, czyli rysowanie mapy oraz widoku miejscowego kościoła, nastąpiła już w Berlinie, a odbiorca gotowych prac nie był tym samym, kto nadzorował pomiary pod Fryburgiem. Nie było zatem naocznego świadka obecnego na każdym etapie „eksperymentu”. Meydenbauer zredagował zatem artykuł, w którym użyte środki przywodzą na myśl próbę nadrobienia nieciągłości inscenizacji. Przede wszystkim tekst pt. Die Photogrammetrie został wydany anonimowo, w formie relacji amatora zainteresowanego nowinkami technicznymi, aktualnie składającego świadectwo o rozwoju fotogrametrii ${ }^{27}$. „Sprawozdawca” w pierwszej części tekstu podawał wszystkie informacje pod kątem zarysowania odpowiedniego tła dla drugiej części, w której opisał widziane na paryskiej Wystawie Światowej zdjęcia i urządzenie Laussedata. Najpierw przedstawiono zalety maszyny zbudowanej przez „pana Meydenbauera”, i poinformowano, że „przejęła ona na siebie” pracę fizyczną, z którą łączyło się dotychczasowe zdejmowanie wymiarów terenu i budynków. We fragmencie poświęconym pomiarom pod Fryburgiem Meydenbauer przekuł potencjalne źródło niepewności w atut - oddalenie rysownika, „który nigdy nie był w okolicy Frybur-

25 Ragey, The Work of Laussedat..., s. 22.

${ }^{26}$ Meydenbauer posługiwał się jako jednostką długości prętem pruskim (Rute), odpowiadającym w przybliżeniu 3,77 m, zob. A. Martini, Manuale di metrologia, Turin 1883, s. 74. Mierzony obszar miał mieć 400 prętów długości i 350 prętów szerokości, zob. [Meydenbauer], Die Photogrammetrie, s. 471.

27 Ibidem, s. 471-472. 
ga"28, nie posiłkował się też innymi planami, a mimo to stworzył „poprawne, kompletne przedstawienie" tamtejszych terenów, miało przekonać czytelnika o obiektywnej ewaluacji zebranych danych.

Druga część artykułu miała z kolei sprawić, by doceniono osiągnięcia rodzimego wynalazcy. „Sprawozdawca” opisał bowiem szczegóły swojego zetknięcia się jeszcze w tym samym roku w Paryżu z efektami analogicznych eksperymentów, niedorównującymi jednak wynikom Meydenbauera. W relacji podkreślono, że mapy Alp wykonane przez Laussedata dowodziły użyteczności fotografii $\mathrm{w}$ pomiarach terenu, zarazem jednak autor wymienił niedociągnięcia i anachronizmy techniczne aparatu Francuza, jak też brak zastosowania metody do pomiarów budynków. W tym kontekście uwypuklone zostały przewagi „pana Meydenbauera” - zarówno jako twórcy doskonalszego sprzętu, jak i pomysłodawcy rozszerzenia jego użycia. W artykule widać też chęć wzbudzenia ducha rywalizacji w ewentualnych odbiorcach z kręgów rządowych lub wojskowych, poprzez stwierdzenie, że metoda Laussedata „wydaje się być tajemnicą rządu francuskiego, skrytą w półurzędowym, chronionym wojskową strażą milczeniu”29. Autor „kusił” również praktycznością konstrukcji aparatu, którego obsługa dla odpowiednio przeszkolonego operatora miała nie stanowić problemu, a sprzęt mógł być odtworzony według schematu w dowolnym miejscu, dzięki szerokiej dostępności części wykorzystanych do jego budowy.

Mobilizacja sojuszników powiodła się jednak tylko tymczasowo - raz zdobyte wsparcie musi być bowiem nieustannie pielęgnowane, a wszelkie porażki na początkowym etapie współpracy są brzemienne w skutki. Pierwsze niepowodzenie, czyli wspomniane pomiary pod Strasburgiem w czasie wojny prusko-francuskiej w roku 1870, mocno podkopały zaufanie do metody. Nie miało znaczenia, że Meydenbauer nie mógł być obecny w trakcie tego przedsięwzięcia, gdyż stacjonował w innym miejscu, powołany do Oddziału Kolei Polowych $\mathrm{Nr}^{30}$. Zdążył tylko wykonać projekt nowego aparatu pomiarowego, nad którego wykonaniem miał czuwać jego przyjaciel, fotograf i wynalazca Franz Stolze - on też miał obsługiwać gotowy sprzęt. Jako że także Stolze został powołany do służby wojskowej, do prowadzenia pomiarów zgłosił się oficer rezerwy Richard Doergens, docent geodezji na berlińskiej Akademii Budowlanej. Nowy aparat nie był jednak wykonany z należytą starannością, a Doergens nie został przeszkolony w jego obsłudze, przez co uzyskane dane rozmijały się z rzeczywistością. Po demobilizacji Meydenbauerowi nie zapro-

\footnotetext{
28 Ibidem, s. 471.

29 Ibidem, s. 472.

${ }^{30}$ Meyer, Albrecht Meydenbauer..., s. 22.
} 
ponowano zatem stałej współpracy - oddelegowano go do nadzorowania przygotowań do budowy kolei mozelskiej.

Być może jego dalsza ścieżka zawodowa składałaby się wyłącznie z kolejno obejmowanych stanowisk w administracji budowlanej, gdyby Meydenbauer w miarę możliwości nie przeprowadzał kolejnych prób fotogrametrycznych, a zwłaszcza - gdyby nie wypatrywał osób, którym mógłby przedłożyć rezultaty. Gdy w roku 1876 poznał Heinricha von Dehn-Rotfelsera ${ }^{31}$, nowego przełożonego do spraw artystycznych, stanął w obliczu kolejnej szansy uzyskania wsparcia dla swej metody - tym razem nie ze środowiska wojskowych, lecz $z$ kręgu urzędników zaangażowanych w tworzenie administracji ochrony zabytków. Dehn-Rotfelser był w stanie ocenić użyteczność fotogrametrii, a także zwrócić na nią uwagę ministra wyznań, gdyż był już uznanym architektem i konserwatorem, miał też na koncie współautorstwo pierwszego profesjonalnie opracowanego pruskiego inwentarza ${ }^{32}$. Dehn-Rotfelser rzeczywiście zainteresował się przedłożonymi mu przez Meydenbauera pracami, jednak możliwości organizacji wsparcia zyskał dopiero później, gdy w roku 1881 został państwowym konserwatorem zabytków. W tym samym roku ministrem wyznań został Gustav von Gossler, zainteresowany rozwojem nie tylko konserwatorstwa, ale też nauk stosowanych - Meydenbauer ze swoją metodą „wpasowywał” się idealnie w bieg wypadków.

\section{TO NIE JEST KRAJ DLA KONSERWATORÓW - CZYLI O PRAKTYCZNYCH MOŻLIWOŚCIACH OCHRONY ZABYTKÓW W PRUSACH NA POCZĄTKU LAT 80. XIX WIEKU}

Ochrona zabytków w Prusach oczywiście nie zaczęła się dopiero w latach 80., jednak nie stanowiła ona jeszcze sprawnie działającego, rozwiniętego systemu. Co prawda urząd głównego konserwatora utworzono już w roku $1843^{33}$, ale ograniczono go do funkcji doradczych. Rozszerzenie terytorium królestwa o nowe prowincje - Hanower, Nassau, Hesję i Frankfurt w roku 1866 nie oznaczało ani automatycznego poszerzenia „strefy wpływów” pruskiego

31 Ibidem, s. 23.

${ }^{32}$ H. von Dehn-Rotfelser, W. Lotz, Die Baudenkmäler im Regierungsbezirk Cassel, t. 1, Cassel 1870. Inwentarz powstał na zlecenie władz pruskich krótko po zaanektowaniu Kurhesji, zob. W. Speitkamp, Die Verwaltung der Geschichte. Denkmalpflege und Staat in Deutschland 1871-1933, Göttingen 1996, s. 202.

33 A. Meinecke, Geschichte der preußischen Denkmalpflege 1815 bis 1860, Berlin 2013, s. 10. 
konserwatora ${ }^{34}$, ani powołania urzędników lokalnych o podobnych kompetencjach. Również utworzenie Cesarstwa Niemieckiego niczego w tej kwestii nie zmieniło. Nie próbowano ujednolicić pod względem prawnym organizacji opieki nad zabytkami w poszczególnych państwach Rzeszy ${ }^{35}$. Władze niektórych z nich, np. Bawarii i Badenii, dążyły do centralizacji systemu ochrony zabytków, tymczasem polityka Prus w tej dziedzinie poszła w przeciwnym kierunku.

Obowiązki związane z inwentaryzacją i utrzymaniem obiektów uznanych za zabytkowe zostały delegowane na władze poszczególnych prowincji na mocy ustaw dotacyjnych (Dotationsgesetze) z lat 1873 i $1875^{36}$. Przedsięwzięcia konserwatorskie podlegały wprawdzie jurysdykcji Ministerstwa Wyznań Religijnych, Spraw Szkolnych i Medycznych (Ministerium der geistlichen, Unterrichts- und Medizinalangelegenheiten), jednak przed latami 80. nie były traktowane jako szczególnie ważne ${ }^{37}$. Minister miał właściwie związane ręce, jeśli chodzi o interwencję w przedsięwzięcia konserwatorskie. Nie decydował o ich rozpoczęciu - mógł tylko przedstawiać daną sprawę królowi, ewentualnie ponaglać działania odpowiednich władz prowincjonalnych. Przede wszystkim zaś nie miał funduszu, który umożliwiałby szybkie i efektywne reagowanie - dysponował jedynie niewielkimi sumami, które mógł przeznaczyć na doraźne naprawy. Takie rozwiązanie było utrzymywane przez kolejnych królów jako zabezpieczenie przeciw niekontrolowanym przez nich dużym wydatkom ${ }^{38}$.

Źródłami, z których w praktyce można było pozyskać znaczne sumy, był królewski Najwyższy Fundusz Dyspozycyjny (Allerhöchste Dispositionsfonds), a także subwencje państwowe w ramach Extraordinarium budżetu, uchwalane przez Izbę Deputowanych. Zarówno jedno, jak i drugie było jednak osiągalne tylko dla najważniejszych zabytków, wszystko więc zależało od tego, czy wnioskodawcom uda się przekonać króla lub posłów o wyjątkowej wartości budowli, dla której chcieli uzyskać wsparcie finansowe. Oczywiście podań tego typu było bardzo dużo, a ich liczba ciągle wzrastała, gdyż władze prowincji często nie miały lub nie chciały przeznaczyć środków na konserwację zabytków. Tymczasem Ministerstwo Wyznań, zajmujące się selekcją wniosków, często nie dysponowało wystarczającymi informacjami na temat

${ }^{34}$ Dekret z roku 1867 rozszerzał kompetencje Ministerstwa Wyznań na nowe prowincje tylko w zakresie edukacji i administracji medycznej, zob. Das Preußische Kultusministerium..., s. 39.

35 Speitkamp, Die Verwaltung der Geschichte..., s. 154-157.

36 Ibidem, s. 240.

37 Das Preußische Kultusministerium..., s. 27 i 34.

${ }^{38}$ Meinecke, Geschichte der preußischen..., s. 7-8, 10. 
zgłaszanych obiektów. Systematyczna inwentaryzacja stała się więc pilną potrzebą administracyjną - zgodnie ze słowami ministra Gosslera, należało najpierw wiedzieć, „co się ma"39. Dotychczasowe efekty inwentaryzacji prowincjonalnych nie były jednak zadowalające - zamiast służyć podstawowymi informacjami o jak największej liczbie obiektów, często były albo zbyt ogólnikowe i nierzetelne, albo zbyt „naukowe”, hermetyczne ${ }^{40}$. Przede wszystkim zaś w większości brakowało dobrych ilustracji - urzędnicy, którzy musieli opiniować wnioski, znacznie szybciej wykonywaliby swoje zadanie, gdyby mogli od razu naocznie przekonać się o wyglądzie i stanie zachowania zabytku, zamiast czytać długie opisy.

Gosslerowi zależało więc na przyspieszeniu i profesjonalizacji inwentaryzacji, jednak nie mógł niczego narzucić prowincjom, prawnie pod tym względem niezależnym. Problemem byłoby też zdobycie państwowych funduszy na odgórną organizację działań dokumentacyjnych, zwłaszcza że wykonanie pomiarów i rysunków budowli wiązało się z bardzo wysokimi nakładami finansowymi. Przedstawiciele pruskiego Ministerstwa Wyznań byli świadomi olbrzymich środków, które pochłonęła inwentaryzacja zabytków we Francji - zwłaszcza że do kosztów prac pomiarowych i rysunkowych doszły wydatki na dokumentację fotograficzną ${ }^{41}$. Gossler szukał sposobu, który byłby znacznie bardziej ekonomiczny i efektywny - mogła się nim okazać fotogrametria, gdyż dzięki niej możliwe było uzyskanie zarówno dokładnych fotografii, jak też obliczenie na ich podstawie wymiarów budowli oraz sporządzenie rysunków i przekrojów.

\section{PRÓBY AUTONOMIZACJI FOTOGRAMETRII}

Gossler prawdopodobnie dowiedział się o metodzie Meydenbauera, jeszcze zanim został ministrem, gdy pełnił funkcję podsekretarza w Ministerstwie Wyznań. Zaczął pracę w roku 1879, w okresie przełomowym dla nauk stosowanych - właśnie wtedy utworzono w Berlinie pierwszą pruską Wyższą Szkołę Techniczną $a^{42}$, a w ministerstwie wkrótce pojawiła się koncepcja, by fotogrametrię jako naukę stosowaną wykładać na tej uczelni. Najpierw jednak

39 Mowa Gosslera z 8 lutego 1884 roku, zob. Stenographische Berichte über die Verhandlungen des Preußischen Hauses der Abgeordneten/1883/84,2., s. 1304.

40 Speitkamp, Die Verwaltung der Geschichte..., s. 203-204.

${ }^{41}$ Meinecke, Geschichte der preußischen..., s. 10; A. Meydenbauer, Ein deutsches Denkmäler-Archiv (Monumenta Germaniae), „Deutsche Bauzeitung” 1894, 28(102/103), s. 629.

${ }^{42}$ Rürup, Die Technische Universität Berlin 1879-1979..., s. 12. 
zdecydowano się na przeprowadzenie "kursu pilotażowego" - Meydenbauer został zatem w marcu 1881 roku wysłany przez ministra Puttkamera jako wykładowca do Akwizgranu ${ }^{43}$. Dlaczego akurat tam ${ }^{44}$ ? Uczelnia akwizgrańska była ówcześnie jedyną działającą i zarazem liczącą się pruską szkołą techniczną, od roku cieszącą się statusem szkoły wyższej. Wcześniej niewzbudzająca większego zainteresowania władz, w owym czasie stała się użyteczna jako „ogródek eksperymentalny”, w którym testowano różne rozwiązania przed wdrożeniem ich we właśnie formowanej szkole w stolicy.

Powodzenie w Akwizgranie sprawiło, że Gossler już jako minister wyznań utworzył w roku 1882 kurs fotogrametrii w Berlinie ${ }^{45}$ - z tym, że Meydenbauer miał nauczać nie studentów, lecz profesorów, by wykształcić grono osób mogących wykładać fotogrametrię jako przedmiot. Nie był to jednak pomysł łatwy do wdrożenia - wśród potencjalnych słuchaczy znajdował się zarówno Doergens, uprzedzony do Meydenbauera od czasu pomiarów pod Strasburgiem (przynajmniej według samego zainteresowanego ${ }^{46}$ ), a także Hermann Guido Hauck, profesor geometrii przedstawiającej, pracujący właśnie nad własnym projektem urządzenia fotogrametrycznego ${ }^{47}$. Zajęcia okazały się fiaskiem, ze względu na niemal zupełny brak uczestników. Stało się jasne, że nie da się umocować fotogrametrii w berlińskiej szkole technicznej. Patrząc z perspektywy Latoura, stawiało to pod znakiem zapytania dalszy rozwój metody, gdyż wsparcie nawet najważniejszych polityków nie zapewni przetrwania wynalazkowi, jeśli nie podchwycą go i nie zaczną rozpowszechniać inni naukowcy ${ }^{48}$. Gossler i Meydenbauer najwyraźniej jednak uważali, że zamknięta została tylko jedna z możliwych dróg - minister zaczął szukać sposobu na utworzenie samodzielnej instytucji fotogrametrycznej, zaś Meydenbauer napisał z prośbą o wsparcie do referenta ds. uniwersyteckich - Friedricha Althoffa, urzędnika o szerokich znajomościach, uważanego za szarą eminencję Ministerstwa Wyznań. Meydenbauer sugerował w liście, że „tym razem profesorów [należy] zostawić na boku” ${ }^{49}$.

${ }^{43}$ W Akwizgranie prowadził wykłady i zajęcia terenowe (te ostatnie wspólnie z F. Stolzem) w dniach 13-20 marca 1881 roku, zob. Meyer, Albrecht Meydenbauer..., s. 25.

${ }_{44}$ Rudolf Meyer nie podjął się odpowiedzi na to pytanie - stwierdził jedynie, że przyczyną wysłania Meydenbauera do Akwizgranu z pewnością nie było to, iż Akwizgran figurował jako pierwszy w alfabetycznym spisie miejscowości (niem. Aachen), zob. ibidem, s. 25.

45 Ibidem, s. 25-26.

46 Ibidem, s. 23.

47 G. Scheffers, Lehrbuch der darstellenden Geometrie in zwei Bänden, t. 2, Berlin 1920, s. 24.

48 Afeltowicz, Laboratoria $w$ działaniu..., s. 67.

49 Cytat z listu za: Meyer, Albrecht Meydenbauer..., s. 37. 
W takim wypadku jedyną opcją było przekonanie posłów pruskiej Izby Deputowanych, by uchwalili finansowanie prac fotogrametrycznych ze środków państwowych.

Minister wystąpił 8 lutego 1884 roku, podczas omawiania projektu budżetu Ministerstwa Wyznań, z propozycją zastosowania fotogrametrii do odgórnej, państwowej inwentaryzacji, dostarczającej jednolitego, naukowo przygotowanego materiału ${ }^{50}$. Poprzedził go August Reichensperger, poseł znany z wystąpień w obronie zabytków, który przedstawił fotogrametrię jako środek do uwiecznienia dawnych budowli, to uwiecznienie zaś - jako obowiązek spoczywający na niemieckim narodzie i pruskim ludzie ${ }^{51}$. Gossler próbował pozyskać poparcie nieco innymi słowami, kładąc nacisk na niemiecką wynalazczość i pilność, której rezultatem był wynalazek Meydenbauera. Słabością wystąpienia ministra było jednak użycie wyłącznie słownej perswazji - mówiąc o wyjątkowych osiągnięciach metody, np. o fotogramach wykonanych w Persji przez Franza Stolzego przy 40-stopniowym upale, z użyciem worka jako „ciemni”, wskazał jedynie, gdzie zainteresowani mogą się z nimi zapoznać. Był zbytnim optymistą, sądząc, że posłowie z własnej inicjatywy odwiedzą bibliotekę, a tam już doskonałość techniczna fotogramów i powstałych na ich podstawie rysunków obroni się sama.

By osiągnąć sukces, Gossler musiał przedłożyć widzialne dowody i po wiązać je ze słowną argumentacją, czyli niejako wykonać zastępczą inscenizację przed deputowanymi. W późniejszym wystąpieniu, 3 marca 1885 roku, zaprezentował więc zdjęcia oddające pełne spektrum możliwości fotogrametrii, również takich dotąd niemożliwych do uzyskania, np. ujęć wykonanych aparatem odchylonym pod kątem 90 stopni w stosunku do standardowego ustawienia $^{52}$. Nie mówił już przy tym o „odgórnej inwentaryzacji”, gdyż Ministerstwo Finansów sprzeciwiłoby się temu projektowi. Ostateczną propozycją było użycie fotogrametrii tylko do pomiarów najważniejszych zabytków ${ }^{53}$. Dopiero te zabiegi przyniosły efekty - Izba Deputowanych przyznała 30 tysięcy marek na założenie Instytutu Fotogrametrii.

50 Stenographische Berichte... 1883/84,2., s. 1303-1304.

${ }^{51}$ Ibidem, s. 1302.

52 Stenographische Berichte über die Verhandlungen des Preußischen Hauses der Abgeordneten/1885,2., s. 838; o wyznaczeniu w budżecie sumy na „zastosowanie i wykształcenie fotogrametrycznego postępowania”, wynalazku „Meidenbauera”, donosił też „Dziennik Poznański” - sprawozdawca wskazał, że posłowie Reichensperger i Heerman poparli tę inicjatywę, uznając „konieczność pobudzenia i ożywienia zmysłu ludności dla szanowania i utrzymania zabytków sztuki”, zob. „Dziennik Poznański” 5 marca 1885, s. [2].

${ }^{53}$ Raport Gosslera do cesarza, zob. Meyer, Albrecht Meydenbauer..., s. 38. 


\section{FOTOGRAMETRIA I POLITYKA}

O kierunku najwcześniejszych wypraw Meydenbauera częściowo zdecydowało już pierwsze posiedzenie Landtagu, na którym mówiono o jego metodzie - 8 lutego 1884 roku wystąpienie Gosslera zbiegło się bowiem w czasie z mową posła Ignacego Zakrzewskiego na rzecz odnowienia dwóch zabytków wielkopolskich, tj. kościoła Najświętszej Maryi Panny (Marienkirche) w Inowrocławiu oraz kaplicy św. Prokopa (Prokopiuskapelle) w Strzelnie. Przeanalizujmy, co z wypowiedzi Zakrzewskiego mogło przyciągnąć uwagę ministra.

Dlaczego jednak Zakrzewski w ogóle zwracał się z prośbą o pomoc do rządu? Najprawdopodobniej wyczerpane zostały już środki perswazji, które kierowano do strzeleńskiego proboszcza ze strony poznańskiego Towarzystwa Przyjaciół Nauk. Już w roku 1863 krakowski historyk Józef Łepkowski zwrócił uwagę na karygodne zaniedbanie kościoła św. Prokopa, zamienionego na spichlerz proboszczowski ${ }^{54}$. Rażące było zwłaszcza umieszczenie tympanonu erekcyinego w ścianie „rudery, która doń przytyka”. Pobudziło to Towarzystwo do poproszenia proboszcza Martena o znalezienie stosowniejszego miejsca dla "dawnej pamiątki" ${ }^{\prime 2}$. Sprawozdanie TPN za lata 1865-1866 optymistycznie głosi, że „życzeniu Wydziału [stało się] zadość” ${ }^{56}$, tymczasem niemal dwadzieścia lat później Zakrzewski, członek TPN, zwracał uwagę w Izbie Deputowanych na te same kwestie, co Łepkowski w roku $1863^{57}$. Daje to wyobrażenie o dużych trudnościach, najczęściej finansowych i organizacyjnych, $\mathrm{w}$ doprowadzeniu do realizacji nawet - zdawałoby się - mało kłopotliwego przedsięwzięcia.

Na poparcie swej prośby w przypadku rotundy strzeleńskiej Zakrzewski wysunął argument, że jej odnowienie obiecał już król Fryderyk Wilhelm IV, znany z zamiłowania do starożytności - objeżdżając Wielkopolskę zainteresował się budowlą przede wszystkim z powodu jej „bizantyńskiej kopuły”. Z kolei odnośnie kościoła inowrocławskiego poseł podkreślał, że należy go odbudować jako ważny obiekt historyczny, gdyż to tam w roku 1319 toczył

54 J. Łepkowski, O zabytkach Kruszwicy, Gniezna i Krakowa oraz Trzemeszna, Rogoźna, Kcyni, Dobieszewka, Gołańczy, Żnina, Gasawy, Pakości, Kościelca, Inowrocławia, Strzelna i Mogilna, Kraków 1866, s. 181.

55 Sprawozdanie z czynności Towarzystwa Przyjaciół Nauk Poznańskiego od stycznia 1865 do lipca 1866, „Roczniki Towarzystwa Przyjaciół Nauk Poznańskiego” 1866, 4, s. 556.

56 Ibidem.

57 Stenographische Berichte... 1883/84,2., s. 1301. 
się „przed papiezkimi delegatami proces między królem polskim a Krzyżakami o Pomorze" 58 .

Powyższe argumenty wzbudziły zainteresowanie Gosslera, mimo iż podobne prośby były liczne - również na omawianym posiedzeniu Izby pojawiło się kilka podobnych apeli59. Wypowiadający się posłowie zarzucali budowlom zgłaszanym do odbudowy/odnowienia przez innych, że z jakichś względów na to nie zasługują. Podobnie było z postulatami Zakrzewskiego - dlaczego władze miałyby interesować się "dalekim Inowrocławiem”, skoro zabytki w samym sercu państwa pruskiego stały zaniedbane ${ }^{60}$ ? Zakrzewski jednak albo był dobrze rozeznany w ostatnio rozwijających się tendencjach w polityce ministerstwa, albo przez przypadek zwrócił uwagę na kwestie, które zajmowały samego ministra.

Gossler bowiem bardzo żywo interesował się tematyką krzyżacką, zwłaszcza rozwojem stanu posiadania zakonu w krajach niemieckich, oraz rozrostem terytorialnym państwa krzyżackiego na Wschodzie. Minister popierał wszelkie przedsięwzięcia związane w jakiś sposób z Krzyżakami, m.in. przyznanie funduszy na odnowienie kościoła mariackiego w jednym z najważniejszych ośrodków władzy zakonu - Mühlhausen ${ }^{61}$. Prawdopodobnie także dzięki inicjatywie Gosslera zadaniem w konkursie o stypendium Boissoneta w roku 1881 było przeprowadzenie badań budowli zakonu krzyżackiego w Prusach Wschodnich i Zachodnich, a zwłaszcza w Toruniu ${ }^{62}$.

Tenże kierunek zainteresowań ministra sprawił, że jego uwagę natychmiast przyciągnęła wzmianka Zakrzewskiego o procesie przeciwko Krzy-

58 Fragment za „Kurierem Poznańskim” (pisownia oryginalna), który przedrukował mowę Zakrzewskiego w całości, chwaląc posła za podjęcie inicjatywy w tej sprawie, zob. „Kurier Poznański” 10 lutego 1884, s. [1].

59 M.in. w sprawie remontu kościołów: romańskiego, ponorbertiańskiego w Knechtsteden i kolegiaty ottońskiej w Walbeck, zob. Stenographische Berichte... 1883/84,2., s. 12981299 i 1304.

${ }^{60}$ Wypowiedź posła Gerlacha na wstępie mowy na rzecz kolegiaty w Walbeck, ibidem, s. 1304.

${ }^{61}$ O planach dotowania kościoła w Mühlhausen Gossler wspominał w swoim wystąpieniu 8 lutego 1884, zob. ibidem, s. 1303, następnie zaś wyznaczył ten kościół jako jeden z pierwszych i głównych celów Meydenbauera, o czym pisał w raporcie do cesarza, zob. Meyer, Albrecht Meydenbauer..., s. 38.

${ }^{62}$ W konkursie o stypendium Louisa Boissoneta senat Wyższej Szkoły Technicznej w Berlinie wspólnie z ministrem wyznań formułował zadanie, którego miał się podjąć zwycięzca. Selekcji kandydatów dokonywano na podstawie ich kompetencji, poświadczanych pisemnym życiorysem i in. świadectwami, por. ogłoszenie o konkursie w: „Centralblatt der Bauverwaltung" 1882, 1(2), s. 1 . 
żakom, prowadzonym w kościele inowrocławskim. O tym, że chciał jak najszybciej pozyskać więcej informacji na temat obiektu, świadczy fakt, iż na jego polecenie jeszcze w tym samym roku oględzin ruin dokonał pruski konserwator, wspomniany wyżej Heinrich von Dehn-Rotfelser ${ }^{63}$. Rotunda w Strzelnie zaintrygowała ministra prawdopodobnie dzięki powiązaniu jej z królem Fryderykiem Wilhelmem IV. W latach 80. intensywnie rozwijano bowiem propagandę wysławiającą Hohenzollernów, wydawano książki o legendarnych dziejach dynastii ${ }^{64}$, a w wielu miastach wystawiano pomniki królom $z$ tego rodu - w Berlinie od lat 70. przygotowywany był pomnik właśnie Fryderyka Wilhelma IV, odsłonięty w roku $1886^{65}$.

Działania Gosslera świadczyły o jego zaangażowaniu w umacnianie wizerunku światłej władzy państwowej (zainteresowanej „starożytnościami" swych prowincji i uprawnionej do interwencji w ich ochronie) i zarazem w kształtowanie mitu krzyżackiego. Jednak podkreślić trzeba, że jego priorytety nie zawsze pokrywały się z dążeniami innych polityków państwowych, tematyka krzyżacka zaś i wyobrażenie na temat samych Krzyżaków jako bohaterów narodowego mitu musiały być dopiero stopniowo wdrażane, nie zawsze z powodzeniem; np. jeszcze na początku lat 80. XIX wieku, gdy przedstawiciele komitetu odbudowy zamku w Malborku zwrócili się do rządu o przeznaczenie na rzecz ich sprawy środków, które do tej pory wykładano na budowę katedry w Kolonii, odpowiedziano im, że te fundusze były specjalną subwencją uchwaloną na jeden konkretny cel i nie podlegały redystrybucji na inne obiekty ${ }^{66}$. W roku 1885 kolejny wniosek o dofinansowanie prac w Malborku komisja budżetowa odrzuciła, jako że restauracja zamku „była idealnym zadaniem państwa”, które mogło być wypełnione dopiero po rozwiązaniu realnych problemów ${ }^{67}$. Popierający

${ }^{63}$ Informację na temat przyjazdu konserwatora do Inowrocławia 19 października 1884 roku podały władze rejencyjne w liście z 11 października 1884 roku, zob. Akta dotyczące budowy nowego kościoła NMP w Inowrocławiu [1884-1905], Akta Miasta Inowrocławia, Archiwum Państwowe w Bydgoszczy Oddział w Inowrocławiu (dalej: APBOI), sygn. 52/127.

${ }_{64}$ Np. O. Schwebel, Die Sagen der Hohenzollern, wyd. 2, poszerz., Berlin 1886.

${ }^{65}$ H. Rausch, Kulturfigur und Nation. Öffentliche Denkmäler in Paris, Berlin und London, 1848-1914, Oldenbourg 2006, s. 377.

${ }^{66}$ Komitet zwrócił się do ministra wyznań pismem z 3 stycznia 1881 roku, odpowiedź została wystosowana 17 marca 1881 roku, zob. Knapp, Das Schloss Marienburg in Preussen..., s. 85.

67 Sformułowanie tajnego radcy finansowego Lehnerta, zob. Aus dem Protokoll der 12. Sitzung der Budgetkomission des Abgeordnetenhauses, 17. Legislaturperiode, III. Session, Berlin, 3 März 1885, w: Finanzierung des Kulturstaats in Preussen seit 1800, red. R. Zilch, Berlin-München-Boston 2014, s. 339. 
inicjatywę malborską Gossler uznał, że przełamać ten opór da się tylko wypróbowanym sposobem unaocznienia oponentom jakości budowli na wielkoformatowych zdjęciach. Celem jednej z pierwszych misji Meydenbauera ustanowiono zatem Malbork, a wybrane spośród powstałych wówczas fotogramów zebrano w wygodnym do przeglądania albumie ${ }^{68}$. Zadanie malborskie stało się zarazem sposobnością do sprawdzenia stanu rotundy strzeleńskiej.

Meydenbauer wykonał w Strzelnie tylko trzy „strategiczne” zdjęcia, w ramach weryfikacji słów Zakrzewskiego - po jednym ujęciu rotundy od strony z „przylegającą ruderą" (il. 1) i od środka (il. 2), a także jedno ujęcie prezbiterium i transeptu kościoła ponorbertańskiego, sąsiadującego z rotundą (il. 3) ${ }^{69}$. Zdjęcia z roku 1885 można odróżnić od tych zrobionych dwa lata później dzięki ich charakterystycznym cechom formalnym, analogicznym do zdjęć malborskich - odznaczają się kolistym rozjaśnieniem partii środkowej i zaciemnieniem narożników, pośrodku zaś są widoczne pojedyncze jasne plamki ${ }^{70}$. Ten efekt został wyeliminowany przez Meydenbauera dzięki gruntownej przebudowie aparatu w roku $1886^{71}$. Datowanie fotografii ułatwia też fakt, iż na wcześniejszym zdjęciu $z$ fragmentem kościoła ponorbertańskiego widoczne są uszkodzenia powierzchni dachu obiektu, na zdjęciach późniejszych zaś widać już nowe dachówki oraz gruz dachówkowy (il. 4), co świadczy o niedawno przeprowadzonej zmianie pokrycia. Władze rejencyjne niespotykanie szybko sfinansowały remont dachu, wiedząc, że kontrolę stanu zachowania przeprowadza wysłannik rządowy ${ }^{72}$.

${ }^{68} \mathrm{~W}$ wykazach fotografii publikowanych przez Instytut Fotogrametrii albumy oznaczano gwiazdką " " ", por. [A. Meydenbauer], Aufnahmen von Bauwerken nach dem Messbild-Verfahren, „Centralblatt der Bauverwaltung” 1895, 15(14A), s. 151.

69 Pierwotnie naniesione liczby na odwrocie fotografii oznaczają kolejność, w jakiej Meydenbauer odwiedzał kolejne miejscowości oraz numery zdjęć, np. „14.8” oznacza, że Strzelno było czternastą miejscowością, w której pracowała ekipa Instytutu Fotogrametrycznego, a zdjęcie zostało skatalogowane pod numerem „8".

${ }^{70}$ Uwagi na temat cech formalnych zdjęć malborskich oraz reprodukcję fotografii, przedstawiającej jedną z komnat w Pałacu Wielkich Mistrzów, zob. B. Pospieszna, Archiwum fotograficzne malborskiego zarzadu odbudowy zamku (1882-1920), w: Praeterita posteritati. Studia z historii sztuki i kultury ofiarowane Maciejowi Kilarskiemu, red. M. Mierzwiński, Malbork 2001, s. 363-364.

${ }^{71}$ Meyer, Albrecht Meydenbauer..., s. 34.

${ }^{72} \mathrm{O}$ alarmującym stanie dachów informował rejencję zarząd kościelny m.in. w piśmie z 1 marca 1887 roku, zob. Akta dotyczące budowli z funduszu rządowego [1883-1908], w: Akta Miasta Strzelna, APBOI, sygn. 200; już w sierpniu tego samego roku Meydenbauer udokumentował położenie nowych dachówek. 


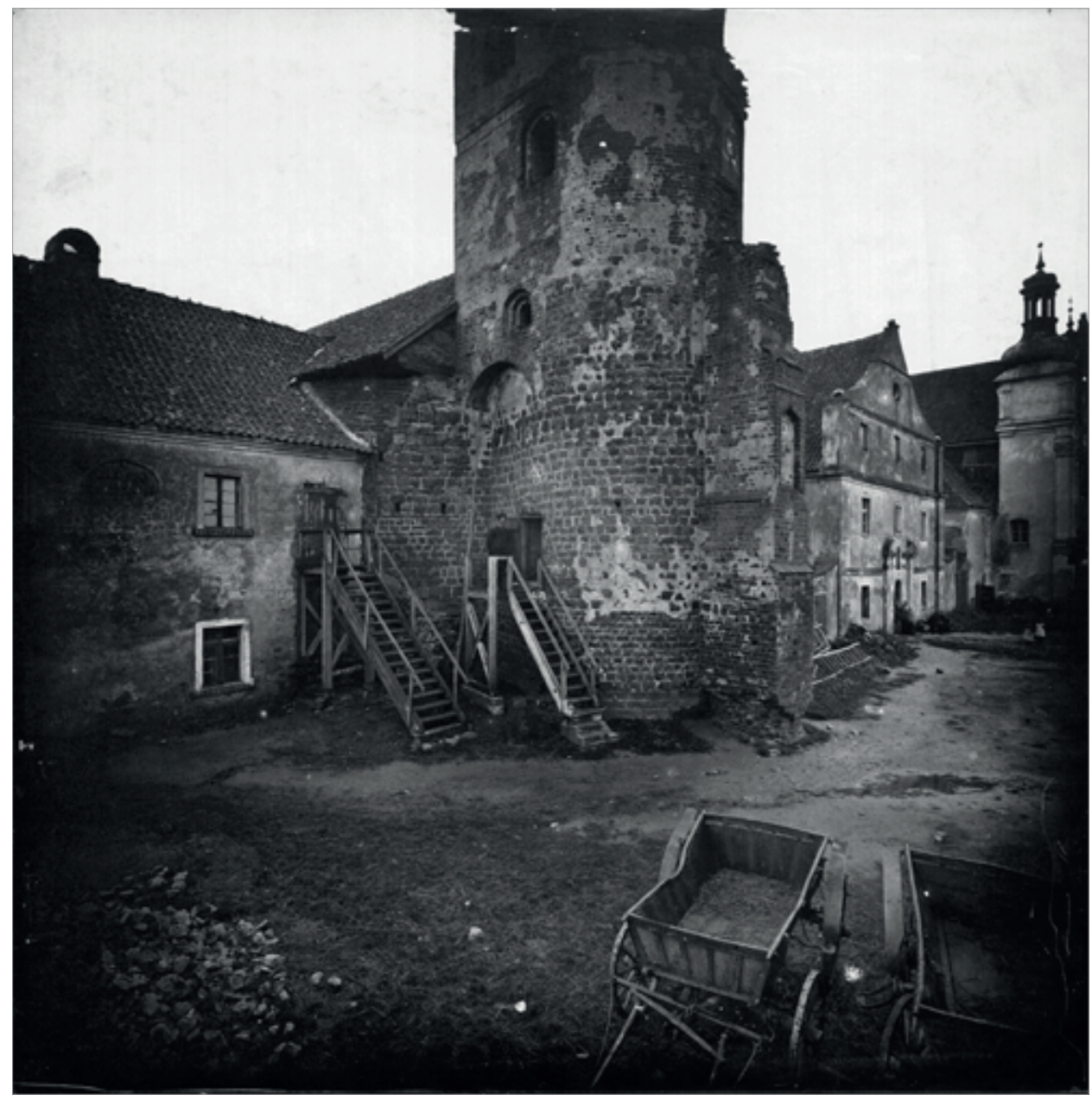

1. Rotunda pw. św. Prokopa w Strzelnie, widok od strony północno-zachodniej, 1885, fot. A. Meydenbauer. Pracownia Zbiorów Ikonograficznych Biblioteki Uniwersyteckiej w Poznaniu, nr 532 (14.8) 


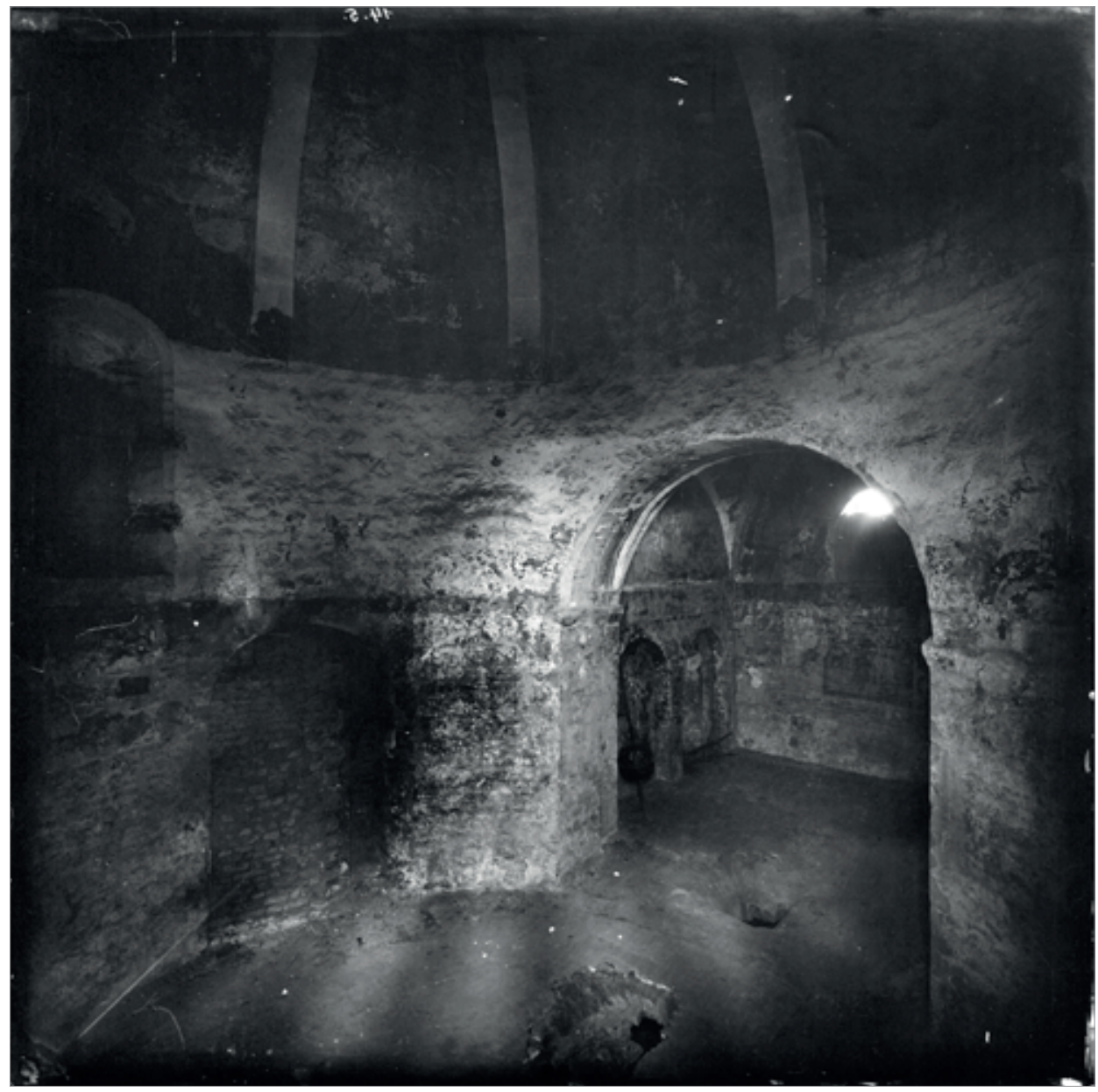

2. Rotunda pw. św. Prokopa w Strzelnie, widok wnętrza, 1885, fot. A. Meydenbauer. Pracownia Zbiorów Ikonograficznych Biblioteki Uniwersyteckiej w Poznaniu, nr 534 (14.5) 


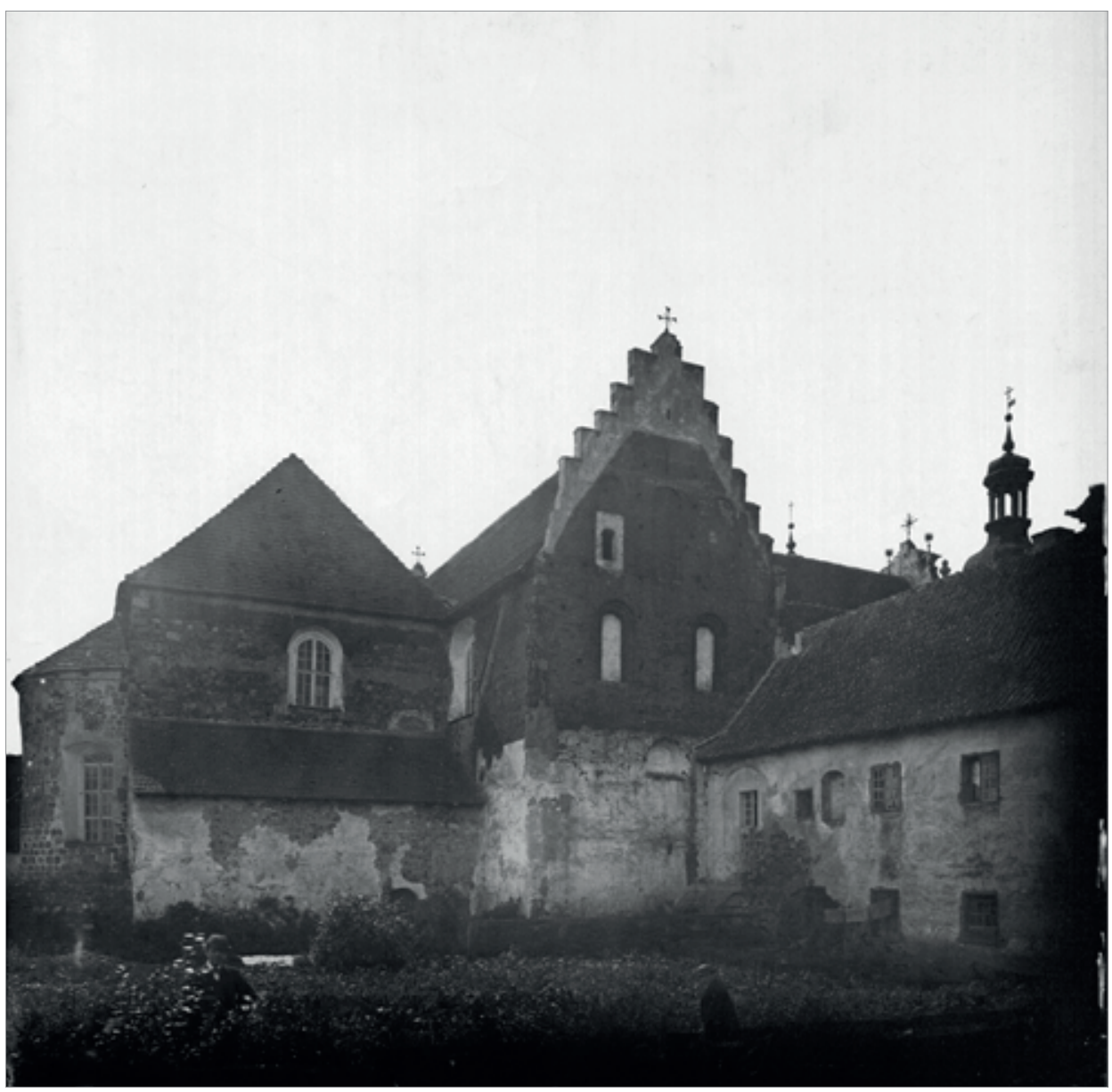

3. Kościół ponorbertański w Strzelnie, widok od strony północno-wschodniej, 1885, fot. A. Meydenbauer. Pracownia Zbiorów Ikonograficznych Biblioteki Uniwersyteckiej w Poznaniu, nr 531 (14.7) 


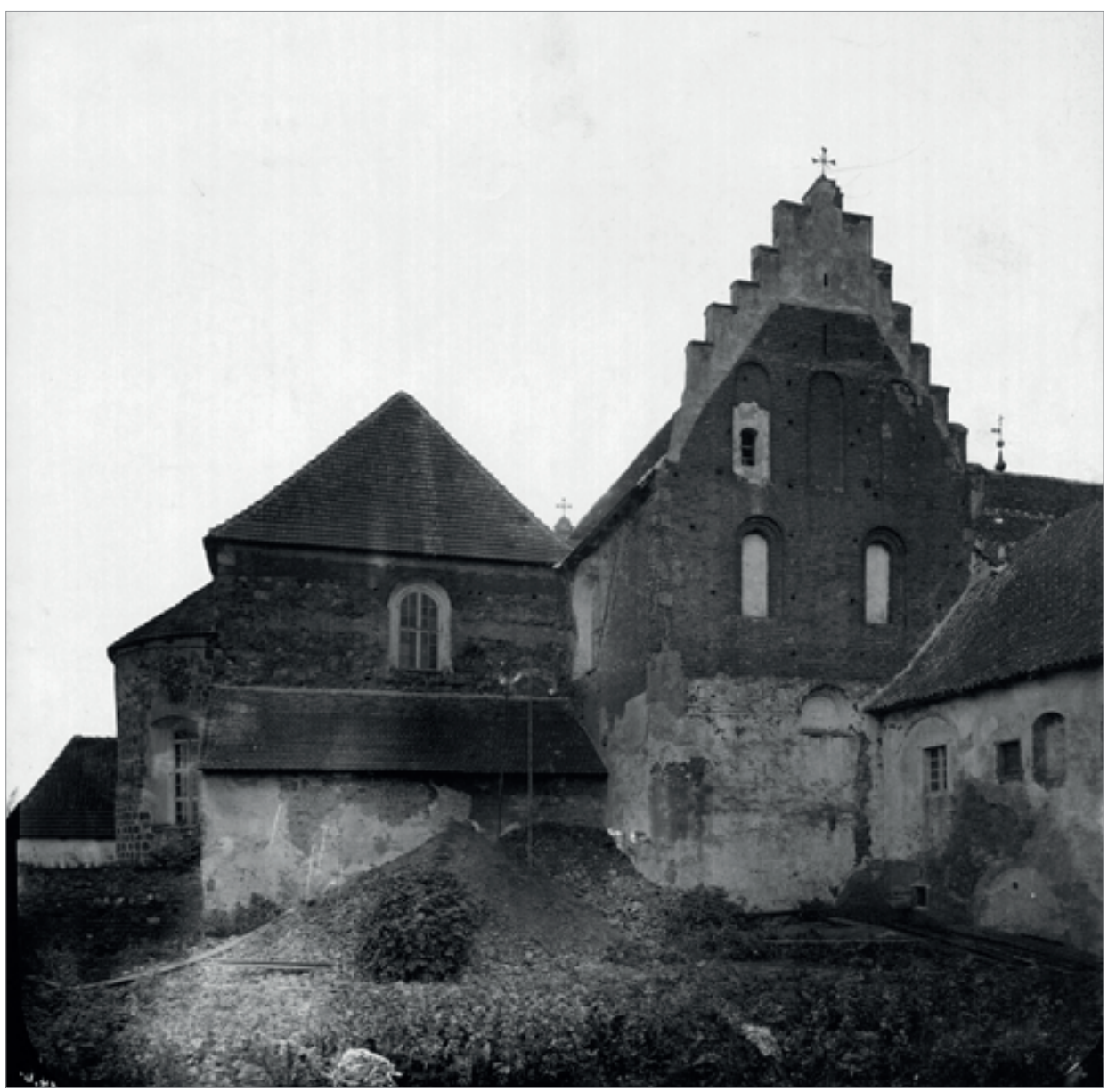

4. Kościół ponorbertański w Strzelnie, widok od strony północno-wschodniej, 1887, fot. A. Meydenbauer. Pracownia Zbiorów Ikonograficznych Biblioteki Uniwersyteckiej w Poznaniu, nr 530 (14.6) 
Pierwsza wizyta Meydenbauera w Poznańskiem wyniknęła zatem przy okazji realizacji większego zlecenia, związanego z zainteresowaniami ministra Gosslera. Podobnie było w przypadku drugiego przyjazdu w roku 1887 - wówczas głównym celem był również silnie związany z problematyką krzyżacką Toruń. Po ok. dwutygodniowym pobycie w tym mieście (25 lipca - ok. 7 sierpnia $)^{73}$ ekipa Meydenbauera spędziła po jednym dniu w Inowrocławiu (10 sierpnia) ${ }^{74}$ i Strzelnie (11 lub 12 sierpnia), dwa dni w Poznaniu (13-14 sierpnia $)^{75}$, a następnie udała się na Śląsk - kolejno do Brzegu, Oleśnicy i Świdnicy ${ }^{76}$.

Kierunek i efekty działalności Instytutu Fotogrametrycznego nie były jednak podporządkowane wyłącznie interesom Gosslera, zwłaszcza że placówka musiała funkcjonować niezależnie od personalnych przetasowań w ministerstwach. Meydenbauer musiał dostosowywać swą ofertę, a także sposób, w jaki ją promował, biorąc pod uwagę różnych potencjalnych odbiorców. W końcowej części artykułu chciałabym rozważyć, do jakich motywacji, sentymentów i dyskursów się przy tym celu odwoływał.

${ }^{73}$ Według własnego raportu Meydenbauer zaczął misję w Toruniu 25 lipca 1887 roku. 7 sierpnia „Thorner Zeitung” odnotował, że „od jakiegoś czasu” w mieście przebywa „Herr Regierungs- und Baurath Meydenbauer”, przybyły w celu wykonania zdjęć miejscowych historycznych dzieł architektury. 18 sierpnia ta sama gazeta pisała, że Meydenbauer w sierpniu spędził w Toruniu pierwszy tydzień miesiąca; zob. Raport z wykonania zdjęć pomiarowych w Prusach Zachodnich, Poznańskiem i na Śląsku, Berlin 1 września 1887 r. (odpis), Akta dotyczące budowy nowego kościoła NMP w Inowrocławiu [1884-1905], Akta Miasta Inowrocławia, APBOI, sygn. 52/127; „Thorner Zeitung” 7 sierpnia 1887, s. [3]; „Thorner Zeitung" 18 sierpnia 1887, s. [3].

74 O pobycie Meydenbauera w Inowrocławiu i w Strzelnie donosił korespondent „Posener Zeitung", wspominając o dacie bytności fotografa jedynie w pierwszym z miast; w wypadku Strzelna stwierdził: „Auch in Strelno soll eine derartige Aufnahme stattgefunden haben”, zob. „Posener Zeitung” 16 sierpnia 1887, s. 6.

75 Meydenbauer zameldował się w poznańskim hotelu 13 sierpnia, por. przyp. 4; zdjęcia wykonał 14 sierpnia, o czym informowano w notce: „Von einem Berliner Photographen sind gestern verschiedene Aufnahmen des Rathauses und des alten Katharinenklosters in der Wronkerstrasse gemacht werden”, „Posener Zeitung” 15 sierpnia 1887, s. 2.

76 Zob. Raport z wykonania zdjęć pomiarowych w Prusach Zachodnich..., sygn. 52/127. Przyczyny, które zdecydowały o skierowaniu pracowników Instytutu Fotogrametrycznego do tych trzech miast śląskich, wymagają dalszych badań - wstępne rozeznanie pozwala jedynie stwierdzić, że pobyt w Oleśnicy był uzasadniony pilną potrzebą dokumentacji stanu tamtejszego zamku, który od niedawna stanowił posiadłość następcy tronu i miał zostać poddany gruntownemu remontowi, zob. H. Lütsch, Verzeichnis der Kunstdenkmäler der Provinz Schlesien, Bd. II, Die Landkreise des Reg.-Bezirks Breslau, Breslau 1889 , s. 546-549. 


\section{FOTOGRAMETRIA I PRZEDSIĘBIORCZOŚĆ}

We wspomnianym anonimowym artykule z roku 1867, kierowanym do architektów i polityków, Meydenbauer skupił się na wychwalaniu technicznych możliwości metody oraz podkreślaniu jej przewag w stosunku do eksperymentów Francuza Laussedata, tym samym starając się wykorzystać napięcie w relacjach prusko-francuskich. W tekście nieco ponad dwadzieścia lat późniejszym, powstałym już po założeniu Instytutu Fotogrametrii, nacisk został położony na udoskonalenia w budowie aparatu i technice uzyskiwania odbitek ${ }^{77}$. Autor zwracał też uwagę na nowe projekty, np. budowę aparatu do powiększeń. Konkluzją było stwierdzenie, że środki przyznane na instytut zostały należycie wykorzystane, gdyż udało się dopracować metodę sporządzania prawidłowych rysunków architektonicznych na podstawie zdjęć, a zarazem zachować wymóg ekonomiczności. Artykuł miał zatem podkreślić zgodność osiągnięć instytutu z oczekiwaniami, które zarysował Gossler przy jego powoływaniu.

W końcowych akapitach artykułu autor opisał to, co stanowiło jego osobisty cel, czyli wizję utworzenia archiwum zabytków na bazie materiału gromadzonego przez Instytut. Projektowany zbiór miał obejmować wizerunki najbardziej wartościowych dzieł architektonicznych, które Meydenbauer określił jako „pomniki” (Baudenkmäler), „w których [odbijają się] wszystkie umiejętności i wiedza przodków"78. Nie dokonywał przy tym rozróżnień na poszczególne epoki czy narody. Brak powodzenia w pozyskiwaniu sojuszników dla tego projektu skłonił jednak Meydenbauera do wykorzystania dyskursu narodowego, zyskującego coraz większą popularność w ramach tzw. badań wschodnich (Ostforschung) ${ }^{79}$. Tekst z roku 1894 nosi już tytuł Ein deutsches Denkmälerarchiv (Monumenta Germaniae), a znaleźć w nim można np. opinię, że twórczość niemieckich mistrzów jest rozpoznawalna „nawet na głębokim Wschodzie", gdzie przyczyniła się do rozwoju sztuki bardziej niż działalność miejscowych ${ }^{80}$. Meydenbauer stwierdzał dalej, że przegląd „pracy

77 [A. Meydenbauer], Die Messbildkunst und das Denkmäler-Archiv, „Centralblatt der Bauverwaltung" 1888, 8(45), s. 482-483.

78 Ibidem, s. 483.

79 Badania nad niemiecką kolonizacją wschodnią, ukazywaną jako misja kulturowa w zacofanej cywilizacyjnie Europie Środkowo-Wschodniej, zob. A.S. Labuda, „...eine von sinnvollen Zweckgefühlen erfüllte, herbe und großartige Kolonialkunst...". Europa Środkowo-Wschodnia w dyskursie historii sztuki, w: idem, Z dziejów historii sztuki. Polska, Niemcy, Europa, Poznań 2016, s. 40-41.

${ }^{80}$ Meydenbauer, Ein deutsches Denkmäler-Archiv..., s. 629. 
artystycznej niemieckich ludów" ${ }^{\prime \prime}$, który ożywi uczucia wspólnotowe dzięki ukazaniu wcześniejszych kolektywnych dokonań, będzie możliwy właśnie przez utworzenie niemieckiego archiwum zabytków. „Niemieckość” i „praca kulturowa" na Wschodzie zostały wplecione w promocję własnych koncepcji. Meydenbauer wprawdzie dodał do wcześniejszych wywodów, że ostatecznym celem jest stworzenie takich archiwów przez każdy naród, by otrzymać „obraz rozwoju [...] najważniejszych ludzkich dokonań w ogóle" ${ }^{82}$, niemniej jednak zastosowane przez niego argumenty stanowiły przyczynek, który wraz z wieloma mu podobnymi umacniał dyskurs narodowy i szerzył przekonanie o niemieckiej wyższości kulturowej.

W swych tekstach Meydenbauer nie prezentował jednak konsekwentnie tego typu postawy - stosował różnorodną argumentację, często powtarzając stwierdzenia publikowane gdzie indziej. Zapożyczał na własny użytek wypowiedzi innych, nawet zbytnio ich nie przeredagowując. Prawdopodobnie robił to celowo - by pochwycić uwagę osoby, która pierwotnie użyła danego sformułowania. Takiego zabiegu dokonał w przytoczonym już artykule z roku 1894, przypuszczalnie, by zainteresować fotogramami Hermanna Grimma, pierwszego berlińskiego profesora historii sztuki. Dla Grimma nowoczesne aparaty rejestrujące i odtwarzające obrazy były niezbędnymi narzędziami badawczymi i wykładowymi ${ }^{83}$, elementami współtworzącymi siłę perswazji mówcy. Rzutnik - skioptikon, jako maszyna miał „użyczać” swego niezawisłego autorytetu interpretatorowi pokazywanych obrazów, przekonując audytorium, że twierdzenia wykładowcy nie były jego subiektywnym wyobrażeniem, ale miały status prawdy - tak jak w eksperymentach angielskich empirystów. Była to rozwinięta forma inscenizacji, jeszcze bardziej kojarząca się z teatrem, gdyż Grimm dbał o zaciemnienie sali i skupienie w ten sposób uwagi słuchaczy na „pojawiających się na ścianie” obrazach. Tego typu wykłady prowadził od roku 1892, lansując użycie rzutnika lub dwóch jako niezrównaną pomoc, umożliwiającą porównywanie ze sobą obrazów czy analizę powiększonych fragmentów ${ }^{84}$. Zestawianie ze sobą fotografii wydobywających każdy szczegół miało przynosić znacznie bardziej obiektywne wnioski niż bezpośredni ogląd. Chyba żadna inna opinia nie mogłaby bardziej odpowiadać Meydenbauerowi.

Twórca fotogrametrii we własnym artykule nadmienił, że fotogramy stanowią niezastąpiony materiał do badań, gdyż można porównywać ze sobą

81 Ibidem.

82 Ibidem, s. 631.

${ }^{83}$ H. Bredekamp, A.S. Labuda, Od Grimma do Pindera. Zinstytucjonalizowana historia sztuki na Uniwersytecie Berlińskim 1873-1945, w: Labuda, Z dziejów historii sztuki..., s. 188 .

${ }^{84}$ Ibidem, s. 189-190. 
poszczególne widoki bez konieczności „biegania z jednej strony budynku na drugą"85. "Zdjęcia pomiarowe”, a zwłaszcza ich powiększone wersje, umożliwiały ogląd fragmentów niedostępnych ludzkiemu oku albo ze względu na utrudnioną dostępność, albo ze względu na niedostatek światła. Fotografie, jako powstałe dzięki „matematycznie skonstruowanym” urządzeniom, miały stanowić odzwierciedlenie stanu rzeczywistego, niezniekształconego „czynnikiem ludzkim".

Grimm, a z nim Meydenbauer, podkreślali niezawisłość, jaką zyskiwał badacz posługujący się fotografiami. Grimm chciał zaznaczyć niezależność historyków sztuki od kolekcji muzealnych, z kolei Meydenbauer kierował się do badaczy, którzy np. nie mieli możliwości uczestnictwa w zagranicznych ekspedycjach - dzięki zdjęciom dalekie i kosztowne wyjazdy nie były im już potrzebne, by badać dzieła architektury i wypracowywać na ich temat teorie. Grimm pozostawił swoim następcom rozbudowaną fototekę, a Meydenbauer zaopatrzył niemieckie uniwersytety w materiały do zajęć z historii architektury $^{86}$ - obaj zatem, przedsiębiorczo realizując własne interesy i wykorzystując do tego określone urządzenia, współtworzyli podejścia badawcze historii sztuki i architektury, a także metody ich późniejszego nauczania. O ich trwałości świadczy fakt, że do dziś większość studenckich analiz dzieł sztuki jest prowadzona w oparciu o fotografie - i choć zdjęcia nie są już uważane za obiektywny środek pomocniczy w badaniach, to jednak wciąż za najwygodniejszy.

\section{POD POKRYWĄ CZARNEJ SKRZYNKI - KONKLUZJE}

W toku powyższych rozważań pragnęłam uwypuklić, jak skomplikowane powiązania doprowadziły do tego, że Albrecht Meydenbauer znalazł się w Poznańskiem. Moim celem było zwrócenie uwagi na to, że nawet proste i na pierwszy rzut oka szeregowe zdarzenia miały zróżnicowane podłoże, a wdrożenie tego czy innego rozwiązania wymagało najpierw przygotowania odpowiednich warunków - „torów dla lokomotywy". Ich tworzenie prawie nigdy nie przebiegało gładko - w obliczu nieprzewidzianych sytuacji i trudności technicznych plany musiały być zmieniane. To właśnie sekwencja tych zmian, czyli tego, co się nie powiodło, doprowadziła Meydenbauera do specjalizacji w pomiarach budynków i do kierowniczego stanowiska w Instytucie Fotogrametrii. Gdyby zaś nie brak efektywności działań poznańskiego TPN, Zakrzewski nie zwróciłby się do władz o interwencję w sprawie zabyt-

\footnotetext{
${ }^{85}$ Meydenbauer, Ein deutsches Denkmäler-Archiv..., s. 630.

${ }^{86}$ Postarał się u Althoffa o dofinansowanie tego przedsięwzięcia, zob. ibidem, s. 630.
} 
ków wielkopolskich. Ani Meydenbauer, ani Zakrzewski nie osiągnęliby jednak zbyt wiele, gdyby nie określony kierunek polityki Ministerstwa Wyznań i zainteresowania samego ministra, a także - splot interesów, prowadzący do emancypacji nauk stosowanych. Z kolei próby zdobycia dodatkowych środków na działalność Instytutu i realizację projektu utworzenia archiwum zabytków spowodowały czynne „podłączanie” się argumentacji Meydenbauera do autorytetu silniejszych dyskursów - naukowego i narodowego - co zarazem przyczyniało się do ich współtworzenia i dalszego wzmacniania.

Rezultat niniejszych dociekań nie ogranicza się do poszerzenia zbioru faktów. Analiza kolejnych przekształceń kierunku działań jednostek czy treści ich pomysłów pozwoliła też odpowiedzieć na pytania, dlaczego coś się zdarzyło, dlaczego akurat w ten sposób i dlaczego w tamtym konkretnym momencie? Kierowałam się tym, by myśląc o XIX wieku, ówczesnej ochronie zabytków i relacjach polsko-niemieckich, nie postrzegać tych haseł jako „czarnych skrzynek", lecz starać się je rozmontować - pod gładką powierzchnią kryła się bowiem plątanina przewodów i ich węzłów. Rzecz w tym, by śledzić te kruche powiązania, nie zaś przystępować do pracy z „rozmaitymi analitycznymi skalpelami" ${ }^{\prime 87}$. Za Latourem chcę podkreślić, że wszelkie zjawiska rozgrywają się w zbiorowości i trzeba je analizować w relacji ze zbiorowością na każdym etapie ich rozwoju, nie zaś oddzielać „wyjaśnianie w wymiarze społecznym” od zasadniczej treści naukowej. Wtedy łatwiej będzie dostrzec, że zmiany nie pojawiały się wraz z „duchem epoki” czy też według wewnętrznej logiki rozwoju dyscypliny. Dokonywały się one dzięki usiłowaniom jednostek i grup, powiązanych na różne sposoby i znajdujących w tym gąszczu nowe drogi osiągania cenionych wartości, czyli - wykazujących się przedsiębiorczością w działaniu.

\section{BIBLIOGRAFIA}

Źródła archiwalne

Akta dotyczące budowy nowego kościoła NMP w Inowrocławiu [1884-1905], Akta Miasta Inowrocławia, Archiwum Państwowe w Bydgoszczy Oddział w Inowrocławiu (dalej APBOI), sygn. 52/127

Akta dotyczące budowli z funduszu rządowego [1883-1908], w: Akta Miasta Strzelna, APBOI, sygn. 200

Odbitki z negatywów Albrechta Meydenbauera, wykonane przez Königliche Preussische Messbild-Anstalt w Berlinie w 1906 roku, przechowywane w Pracowni Zbiorów Fotograficznych Biblioteki Uniwersyteckiej w Poznaniu, nr 530 (14.6), 531 (14.7), 532 (14.8), 534 (14.5)

\footnotetext{
${ }^{87}$ Latour, Krwiobieg nauki..., s. 145.
} 


\section{Źródła drukowane}

[Meydenbauer A.], Die Photogrammetrie, „Wochenblatt Architekten-Vereins zu Berlin" 1867, 1(49), s. 471-472

[Meydenbauer A.], Die Messbildkunst und das Denkmäler-Archiv, „Centralblatt der Bauverwaltung" 1888, 8(45), s. 482-483

Meydenbauer A., Ein deutsches Denkmäler-Archiv (Monumenta Germaniae), „Deutsche Bauzeitung" 1894, 28(102/103), s. 629-631

[Meydenbauer A.], Aufnahmen von Bauwerken nach dem Messbild-Verfahren, „Centralblatt der Bauverwaltung" 1895, 15(14A), s. 149-152

Sprawozdanie z czynności Towarzystwa Przyjaciół Nauk Poznańskiego od stycznia 1865 do lipca 1866, w: „Roczniki Towarzystwa Przyjaciół Nauk Poznańskiego” 1866,4 , s. $553-558$

Stenographische Berichte über die Verhandlungen des Preußischen Hauses der Abgeordneten/1883/84,2

Stenographische Berichte über die Verhandlungen des Preußischen Hauses der Abgeordneten $/ 1885,2$

Strelno, Prokopiuskapelle. Inowrazlaw, Marienkirche. Posen, Rathaus \& Kapelle, album fotografii wydany przez Königliche Preussische Messbild-Anstalt w Berlinie [b.d.w.], przechowywany w Muzeum Historii Miasta Poznania, sygn. D. $1580 / 1-28$

\section{Gazety}

„Dziennik Poznański” 5 marca 1885

„Kurier Poznański” 10 lutego 1884

„Kurier Poznański” 17 sierpnia 1887

„Posener Zeitung” 13 sierpnia 1887

„Posener Zeitung” 15 sierpnia 1887

„Posener Zeitung” 16 sierpnia 1887

"Thorner Zeitung" 7 sierpnia 1887

\section{Opracowania}

Afeltowicz Ł., Laboratoria $w$ działaniu. Innowacja technologiczna $w$ świetle antropologii nauki, Warszawa 2011

Albertz J., Albrecht Meydenbauer - Pioneer of photogrammetric documentation of the cultural heritage, w: Surveying and Documentation of Historic Buildings, Monuments, Sites: Traditional and Modern Methods. Proceedings of the XVIII International Symposium of CIPA 2001, Potsdam (Germany), September 18-21, 2001, red. J. Albertz, ICOMOS, UNESCO, ISPRS, Berlin 2002, s. 19-25

Barth F., "Models" reconsidered, w: idem, Process and form in social life. Selected essays of Fredrik Barth, t. 1, London 1981, s. 76-104

Barth F., A Personal View of Present Tasks and Priorities in Cultural and Social Anthropology, w: Assesing Cultural Anthropology, red. R. Borowsky, New York 1994, s. $349-361$ 
Barth F., W stronę pełniejszego opisu i głębszej analizy zjawisk kulturowych, tłum. A. Bereza, w: Badanie kultury. Kontynuacje, red. M. Kempny, E. Nowicka, Warszawa 2004, s. 180-192

Bredekamp H., A.S. Labuda, Od Grimma do Pindera. Zinstytucjonalizowana historia sztuki na Uniwersytecie Berlińskim 1873-1945, w: A.S. Labuda, Z dziejów historii sztuki. Polska, Niemcy, Europa, Poznań 2016, s. 183-214

Danielewski M., Reliefy z murów kościoła Panny Marii w Inowrocławiu, „Roczniki Historyczne" 2011, 76, s. 7-34

Danielewski M., Romańskie zabytki architektury sakralnej Inowrocławia i Strzelna w świetle fotografii Meydenlendera z 1887 roku, „Archiwa Biblioteki i Muzea Kościelne" 2012, 98, s. 27-50

Danielewski M., Fotografie z 1887 roku jako źródło ikonograficzne badań nad romańska architekturq sakralnq Strzelna, w: Z dziejów pogranicza kujawsko-wielkopolskiego, t. 3, red. D. Karczewski, M. Wilczek-Karczewska, Strzelno-Kruszwica 2015, s. 105-120

Das Preußische Kultusministerium als Staatsbehörde und gesellschaftliche Agentur (1817-1934), t. 1.1: Die Behörde und ihr höheres Personal. Darstellung, red. W. Neugebauer, Berlin 2009

Dehn-Rotfelser H., W. Lotz, Die Baudenkmäler im Regierungsbezirk Cassel, t. 1, Cassel 1870

Finanzierung des Kulturstaats in Preussen seit 1800, red. R. Zilch, Berlin-MünchenBoston 2014

Grimm A., A. Meydenbauer, 120 Tahre Photogrammetrie in Deutschland. Tagebuch von Albrecht Meydenbauer, dem Nestor des Messbild-Verfahrens, veröffentlicht aus Anlass des Jubiläums 1858/1978, red. A. Grimm, Oldenbourg 1978

Knapp H., Das Schloss Marienburg in Preussen. Quellen und Materialien zur Baugeschichte nach 1456, Lüneburg 1990

König W., Technical education and industrial performance in Germany. A triumph of heterogeneity, w: Education, Technology and Industrial Performance in Europe, 1850-1939, red. R. Fox, A. Guagnini, Cambridge 1993, s. 65-88

Labuda A.S., „...eine von sinnvollen Zweckgefühlen erfüllte, herbe und großartige Kolonialkunst...". Europa Środkowo-Wschodnia w dyskursie historii sztuki, w: idem, Z dziejów historii sztuki. Polska, Niemcy, Europa, Poznań 2016, s. 39-68

Latour B., Krwiobieg nauki. Przykład naukowej inteligencji Joliota, w: idem, Nadzieja Pandory, tłum. K. Abriszewski, A. Derra, M. Smoczyński, M. Wróblewski, M. Zuber, Toruń 2013, s. 113-148

Lütsch H., Verzeichnis der Kunstdenkmäler der Provinz Schlesien, Bd. II, Die Landkreise des Reg.-Bezirks Breslau, Breslau 1889, s. 546-549

Łepkowski J., O zabytkach Kruszwicy, Gniezna i Krakowa oraz Trzemeszna, Rogoźna, Kcyni, Dobieszewka, Gołańczy, Żnina, Gąsawy, Pakości, Kościelca, Inowrocławia, Strzelna i Mogilna, Kraków 1866

Martini A., Manuale di metrologia, Turin 1883

Meinecke A., Geschichte der preußischen Denkmalpflege 1815 bis 1860, Berlin 2013

Meyer R., Albrecht Meydenbauer. Baukunst in historischen Fotografien, Leipzig 1985 
Mrugalska-Banaszak M., Jeden dzień z ratuszem w tle. Poznań 13 sierpnia 1887, Poznań 2004

Pospieszna B., Archiwum fotograficzne malborskiego zarzadu odbudowy zamku (1882-1920), w: Praeterita posteritati. Studia z historii sztuki i kultury ofiarowane Maciejowi Kilarskiemu, red. M. Mierzwiński, Malbork 2001, s. 359-382

Ragey L., The Work of Laussedat and Education in Photogrammetry at the National School of Arts and Crafts, Paris, „Photogrammetric Engineering” 1952, 1(18), s. 21-26

Rausch H., Kulturfigur und Nation. Öffentliche Denkmäler in Paris, Berlin und London, 1848-1914, Oldenbourg 2006

Rürup R., Die Technische Universität Berlin 1879-1979. Grundzüge und Probleme ihrer Geschichte, w: Wissenschaft und Gesellschaft. Beiträge zur Geschichte der Technische Universität Berlin 1879-1979, red. R. Rürup, Berlin1979, s. 3-47

Sachsse R., Vogel, Hermann Wilhelm (1834-1898). German inventor, photographer, w: Encyclopedia of nineteenth-century photography, red. J. Hannavy, New York 2008, s. 1455-1456

Sady W., Spór o racjonalność naukowa. Od Poincarégo do Laudana, Toruń 2013

Scheffers G., Lehrbuch der Darstellenden Geometrie in zwei Bänden, t. 2, Berlin 1920 Schwebel O., Die Sagen der Hohenzollern, wyd. 2, poszerz., Berlin 1886

Shapin S., The house of experiment in seventeenth-century England, „Isis” 1987, 3(79), s. 373-404

Speitkamp W., Die Verwaltung der Geschichte. Denkmalpflege und Staat in Deutschland 1871-1933, Göttingen 1996

Swenson A., „Heritage”, „Patrimoine” und „Kulturerbe”. Eine vergleichende historische Semantik, w: Prädikat „Heritage”. Wertschöpfungen aus kulturellen Ressourcen, red. R. Bendix, D. Hemme, M. Tauschek, Münster 2007, s. 53-74

Treue W., Wirtschafts- und Technikgeschichte Preussens, Berlin-New York 1984

Ewelina Wojdak

Instytut Historii Sztuki

Uniwersytet im. Adama Mickiewicza w Poznaniu

PHOTOGRAMMETRY IN THE WEB OF POLITICS AND BUSINESS.

ALBRECHT MEYDENBAUER IN THE REGION OF POZNAŃ IN 1885 AND 1887

Summary

A standard belief as regards the conservation of architectural monuments in the $19^{\text {th }}$ century is that the very idea of conservation was commonly accepted, while the monuments of the past were used to promote national identity. On the other hand, photography is also commonly considered a technology that was naturally predisposed to popularize those monuments and/or appropriate them as symbols. For those reasons, the photogrammetric documentation of some buildings from the region of Poznan, made 
by Albrecht Meydenbauer commissioned to do it by the Prussian government, could be classified as combination of conservation and nationalism, "typical" of the late $19^{\text {th }}$ century. However, the author proposes another interpretation and claims that such events were not necessarily "realizations" of "widespread" ideas of identity building. Referring to the generative model of identity building developed by Friedrik Barth, she analyzes how specific situations and meanings were gradually generated through the interaction of actors who attempted to reach their goals and values by available means. The introduction and popularization of Meydenbauer's invention is presented in the paper with reference to Bruno Latour's research on the development and implementation of innovations in science. In such a context, photogrammetry turns out to have been a result of seeking support by business, i.e. the mobilization of resources, while the national discourse was used for that purpose as one of the available means.

Keywords:

photogrammetry, national identity, Albrecht Meydenbauer, business resources 